\title{
Cartilhas de alfabetização: a redescoberta do Código Alfabético *
}

\author{
João Batista Araujo e Oliveira**
}

\section{Resumo}

Este artigo analisa as 19 cartilhas de alfabetização aprovadas pelo Ministério da Educação (MEC) para uso nas escolas públicas a partir de 2010. A análise tem por objetivo verificar em que medida foram cumpridos dois dos aspectos centrais do processo de alfabetização estabelecidos pelo Edital: o tratamento das relações fonema/ grafema e o desenvolvimento da fluência de leitura. 0 artigo contrasta as bases conceituais usadas nas orientações gerais do MEC e nas bibliografias citadas pelos autores com o paradigma da Ciência Cognitiva da Leitura. A análise das atividades propostas nas cartilhas demonstra que menos de $1 \%$ das cartilhas ensina a decodificar e nenhuma delas promove a fluência de leitura. 0 artigo discute as razões pelas quais nem os autores seguiram as recomendações do Programa Nacional do Livro Didático (PNLD) nem as autoridades do MEC abriram mão do requisito pelo qual a não observância do Edital, segundo qualquer um dos critérios, resulta em exclusão. E sugere que as concepções de alfabetização subjacentes às propostas analisadas, contrastadas com o paradigma da ciência cognitiva da alfabetização, podem explicar o entendimento dos autores, mas não explicam o descumprimento ostensivo das recomendações do Edital.

Palavras-chave: Alfabetização. Cartilhas. Ciência cognitiva da leitura. Decodificação. Fluência de leitura.

\section{Primers: the rediscovery of the Alphabetic Code Abstract}

This paper analyzes the 19 primers approved by MEC/PNLD for use in public schools from 2010 onwards. The purpose of the paper is to assess the extent to which the authors of the primers complied with two requirements established in the Terms of Reference concerning the central aspects of learning to read: decoding and reading

\footnotetext{
* A análise das cartilhas contou com a colaboração de Juliana Pereira dos Santos e Henrique Rodrigues, professores de Lingua Portuguesa.

** PhD em Educação; Presidente do Instituto Alfa e Beto, Brasília, DF. E-mail: joao@alfaebeto.org.br
} 
fluency. The paper compares the conceptual basis proposed by MEC and the references used by the authors with the paradigm of the Cognitive Science of Reading. The analysis of the primers reveals that less than $1 \%$ of the activities are related to decoding and there are no activities to promote reading fluency. The paper suggests a hypothesis to explain why the authors did not comply with the requirements and why the MEC authorities did not enforce these requirements. The paper also suggests that the underlying ideas of teaching and reading in the books approved by MEC, when compared with the paradigm of the Cognitive Science of Reading may explain the author's interpretation of the Terms of Reference but does not explain the explicit violation of its requirements.

Keywords: Literacy. Primers. Cognitive science of reading. Decoding. Reading fluency.

\section{Cartillas de alfabetización: el redescubrimiento del Código Alfabético Resumen}

El presente artículo analiza las 19 cartillas de alfabetización aprobadas por el MEC/PNLD (Ministerio de Educación de Brasil / Programa Nacional del Libro Didáctico) para uso en las escuelas públicas a partir de 2010. El análisis tiene como objetivo verificar en qué medida dos de los aspectos centrales del proceso de alfabetización establecidos por el Edicto de Licitación se cumplieron: el tratamiento de las relaciones fonema/grafema y el desarrollo de la fluidez de la lectura. El artículo coteja las bases conceptuales usadas en las orientaciones generales del MEC y en las bibliografías citadas por los autores con el paradigma de la Ciencia Cognitiva de la Lectura. El análisis de las actividades propuestas en las cartillas demuestra que menos del 1\% de las cartillas enseña a decodificar y ninguna de ellas promueve la fluidez de la lectura. El artículo discute las razones por las cuales ni los autores siguieron las recomendaciones del PNLD (Programa Nacional del Libro Didáctico) ni las autoridades del MEC desistieron del requisito por el cual la no observancia del Edicto según cualquier criterio resulta en exclusión. También sugiere que las concepciones de alfabetización subyacentes a las propuestas analizadas, cotejadas con el paradigma de la ciencia cognitiva de la alfabetización, pueden explicar la comprensión de los autores, pero no explican el no cumplimiento ostensivo de las recomendaciones del Edicto.

Palabras clave: Alfabetización. Cartillas. Ciencia cognitiva de la lectura. Decodificación. Fluidez de lectura.

\section{Introdução}

0 primeiro desafio da escola é ensinar o aluno a ler e a escrever. Tradicionalmente o termo empregado para caracterizar essa fase inicial do aprendizado da leitura e escrita se chama alfabetização. De acordo com o paradigma da Ciência Cognitiva da 
Leitura (FRITH, 1985), há três etapas críticas nesse processo: primeiro, a criança deve ser capaz de identificar palavras como imagens; segundo, deve ser capaz de identificar os menores componentes das palavras, denominados fonemas, e estabelecer sua relação com os grafemas que lhes correspondem. Terceiro, deve dominar a ortografia, ou seja, as regras que regem a correta grafia das palavras. Dehaene (2007) descreve como o processo de alfabetização modifica o cérebro e também mostra que não há nada de automático - adultos não alfabetizados ou adultos alfabetizados em sistemas silábicos de escrita não possuem a capacidade de identificar fonemas.

A essência da alfabetização situa-se na segunda etapa desses processos, e normalmente ocorre em duas fases distintas, embora, com superposição: a descoberta do princípio alfabético, ou seja, o princípio de que as palavras são constituídas por letras e as letras representam os fonemas - popularmente denominados de "sons" - que são os componentes básicos das palavras. Na segunda fase a criança aprende as valências dos fonemas e a maneira de juntá-los (codificar) ou decompô-los (decodificar) para ler e escrever as palavras. A capacidade de decodificar, isto é, dominar o funcionamento do código alfabético - constitui a essência do processo de alfabetização.

\section{0 paradigma da alfabetização predominante na comunidade científica internacional}

Os estudiosos do tema distinguem três conceitos: aprender a ler, ler e compreender. Aprender a ler refere-se às etapas iniciais de aprendizagem do código, e inclui, também, as fases imediatamente posteriores, especialmente a capacidade de reconhecimento automático de palavras e o desenvolvimento da fluência de leitura. Ler refere-se à capacidade de extrair o som e pronunciar a palavra, isolada ou em frases. Como afirma Perfetti (2003, p.16),

o que uma criança aprende é como funciona o seu sistema de escrita - tanto os princípios básicos como os detalhes da ortografia. Sabemos que essa aprendizagem ocorreu se a criança é capaz de identificar palavras escritas como sendo palavras de sua própria língua, consistentes com o seu sistema de escrita. Para um leitor alfabético, isto significa ler palavras não familiares, inclusive pseudopalavras, tanto quanto ler palavras familiares. A criança aprende muitas outras coisas durante o processo de alfabetização, mas isto é a aprendizagem essencial, à qual devem estar conectadas outras aprendizagem, como, por exemplo, a compreensão.

Compreender refere-se à capacidade de identificar o sentido de uma palavra isolada ou em contexto e relacionar o significado de diversas palavras, frases ou parágrafos de um texto. 0 conceito de escrever é complementar ao conceito de ler; 
no seu sentido próprio escrever significa traduzir os sons da fala usando o código alfabético. A falta de clareza entre o significado e a diferença entre esses conceitos tem levado a importantes equívocos, alguns dos quais serão analisados adiante.

Ser alfabetizado é condição necessária, mas não suficiente, para o progresso e 0 sucesso escolar. As evidências coletadas com os testes do Sistema de Avaliação da Educação Básica (SAEB) e do Programa Internacional de Avaliação de Alunos (PISA) desde 1995 demonstram que um contingente significativo de alunos brasileiros cerca de $50 \%$ ou mais dos alunos da $4^{\mathrm{a}}$, e mesmo da $9^{\mathrm{a}}$, séries, não superam, ou mal superam, a fase de decodificação, que é o cerne da alfabetização ${ }^{1}$. Por outro lado, a análise de testes de leitura voltados para as séries iniciais, em vários paises, demonstra o alto grau de associação entre desempenho nesses testes e domínio do código (NATION; SNOWLING, 1997; KEENAN; BETJEMAN, 2007; KEENAN; BETJEMANN; OLSON, 2008). Vale dizer, a imprecisão/lentidão na identificação das palavras escritas, processo que exige a decodificação, enfraquece o desempenho na compreensão de textos. Quanto mais jovem e inexperiente o leitor, maior o efeito das competências de decodificação em testes de compreensão. Quanto mais experiente é o leitor, mais os resultados de compreensão estão associados à capacidade de compreensão oral. Isso comprova que ler e compreender não são competências equivalentes, são competências interdependentes - para compreender um texto escrito o leitor precisa, antes de mais nada, saber ler. A recíproca, no entanto, não é verdadeira: podemos ler sem compreender.

0 processo de aprendizagem da leitura é independente do processo de compreensão, conforme documentado pelos estudos realizados com hiperléxicos, desde 0 estudo clássico de Seymour e Evans (1992) até estudos mais recentes como o de Cardoso-Martins e Silva (2010). Evidência adicional decorre da constatação de que os processos de compreensão a partir do escrito e do oral são altamente correlacionados, sendo que a compreensão a partir da leitura aumenta em função da fluência (HIRSCHMAN, 2003). De acordo com esse paradigma, o processo de alfabetização requer o domínio de três competências básicas: a consciência fonológica, ou seja, a capacidade de segmentar palavras e de notar que as palavras são compostas por fonemas; o domínio do princípio alfabético, ou seja, o conhecimento de que as letras do alfabeto são símbolos que representam os componentes dos sons que ouvimos na fala, isto é, que os grafemas representam os fonemas². Para que haja compreensão da leitura é necessária uma competência adicional, a fluência. Uma

1 Um teste aplicado pelo Instituto Alfa e Beto em 350 mil alunos de 350 municipios, em outubro de 2009, revelou que 70\% dos alunos do $2^{\circ}$ ao $5^{\circ}$ ano não eram capazes de escrever uma frase sob condições de ditado. Esses dados são consistentes com o fato de que um resultado de 150 pontos na Prova Brasil de Língua Portuguesa da $4^{\text {a }}$ série sugere que mais de 50\% dos alunos são analfabetos.

2 Para escrever é preciso também aprender as regras de notação do sistema ortográfico. 0 primeiro passo, no entanto, consiste em fazer pelo menos uma transcrição alfabética, ou seja, um grafema para cada fonema. $\mathbf{0}$ aspecto central reside na apreensão do conceito de fonema e seu uso prático para ler e escrever. 
pessoa só consegue fazer sentido do que lê se é capaz de ler pelo menos 70 a 80 palavras por minuto, tendo em vista as limitações de processamento da memória de curto prazo. As evidências acumuladas a esse respeito nos últimos 30 a 40 anos vão desde a postulação do processamento automático de informação na leitura por LaBerge e Samuels (1974) até os achados sobre a gestão automática das sacadas e fixações conforme revisão de literatura realizada pelo National Reading Panel Report (2000) nos EUA, doravante denominado NRPR.

0 paradigma científico predominante da alfabetização é conhecido como Ciência Cognitiva da Leitura ${ }^{3}$. Esse paradigma foi desenvolvido ao longo dos anos $70 \mathrm{e}$ 80 e foi fortemente impulsionado pelas descobertas da neurociência ao longo da década de 90.0 marco da mudança de paradigma é a publicação de Adams (1990). As conclusões desse marco foram corroboradas e aprofundadas por Snow, Burns e Griffin (1998), e culminaram com a publicação do National Reading Panel Report (NRPR) (2000). Diversas reanálises e novos estudos realizados a partir desse novo paradigma foram publicados desde então, notadamente o recém-publicado National Early Reading Literacy Panel (2008). 0 relatório sobre Educação Infantil apresentado à Academia Brasileira de Ciências (2009) se insere nessa tradição. Nos últimos anos, os trabalhos de neurocientistas como Dehaene (2007) vêm corroborando as descobertas da psicologia experimental.

Ainda de acordo com as evidências empíricas, a maioria das crianças não faz hipóteses sobre relações entre fonemas e grafemas, ainda que expostas a anos de escolarização (OBSERVATOIRE NACIONAL DE LA LECTURE, 1998). Também de acordo com as evidências experimentais, o ensino sistemático e explícito das relações entre fonemas e grafemas constitui a metodologia mais eficaz para alfabetizar todas as crianças, e mais especialmente, as crianças que demonstram alguma dificuldade de aprender a ler (EHRI et al., 2001). Ou seja: métodos de alfabetização são importantes, fazem diferença e fazem uma diferença muito maior para crianças com dificuldade de aprender a ler e escrever.

\section{0 paradigma da alfabetização predominante no Brasil}

A partir da década de 70 começaram a ganhar impeto, tanto no Brasil como em outros paises, as ideias de Frank Smith $(1971,1973)$, Kenneth Goodman $(1965,1967)$ e, posteriormente, Emilia Ferreiro (1986), a respeito da alfabetização. Por um lado, Smith $(1971,1973)$ postula a ideia de que aprender a ler é tão natural quanto aprender a falar. Para ele a leitura/escrita é modalidade linguística de prática social tanto quanto a comunicação oral. Como o aprendizado da fala se desenvolve a partir da integração em ambientes falantes também o aprendizado da escrita dependeria da imersão em ambi-

3 Um paradigma dominante é identificado mediante diferentes critérios, o mais usual é a presença de artigos científicos publicados nas revistas acadêmicas de circulação internacional com maior rigoroso acadêmico. 
entes letrados. Essa imersão cumpriria papel fundamental na alfabetização. Por outro lado, Goodman $(1965,1967)$ afirma que a leitura é um jogo psicolinguístico de adivinhação. As letras, de fato, atrapalhariam a leitura, a apreensão do significado. Daí a importância do contexto para a leitura. Já a tese central de Ferreiro (1986) e Ferreiro e Teberosky (1989) é que as crianças elaboram hipóteses sobre o valor fonético dos grafemas. Dessa forma, incidentalmente, acabam por dominar o código alfabético 4 .

Essas ideias foram oficializadas com a edição dos Parâmetros Curriculares Nacionais (PCNs), a partir de sua primeira edição em 1997. Elas se tornaram não apenas a orientação oficial, mas a orientação única seguida nos cursos de formação de professores e nas orientações relacionadas à elaboração de materiais didáticos. 0 relatório intitulado Alfabetização infantil: novos caminhos (BRASIL, 2003) revela que, em todas as Universidades Federais que responderam ao questionário enviado para substanciar o relatório, a bibliografia dos cursos de alfabetização era quase sempre limitada a cerca de 5 livros, todos eles publicados na década de 70 a 80 e todos desses mesmos autores que são citados nos documentos dos $\mathrm{PCNs}$. 0 mesmo se pode observar na bibliografia utilizada pelos materiais do curso de formação "Proletramento" produzido pelo Centro de Alfabetização, Leitura e Escrita (CEALE) da Universidade Federal de Minas Gerais (UFMG) e patrocinado pelo Ministério da Educação (MEC), bem como em documentos publicados por secretarias de educação, como, por exemplo, no caso do Rio de Janeiro (RIO DE JANEIRO, 2010).

Cabe notar que, desde a publicação original dos PCNs, não houve mudança significativa nessas bibliografias. Da mesma forma, são raros os livros publicados pelas editoras que disseminam as ideias relativas ao novo paradigma da alfabetização.

Os Editais do Programa Nacional do Livro Didático (PNLD) para a elaboração de cartilhas de alfabetização também mantêm essas caracteristicas. A ênfase na especificação dos itens que devem compor as cartilhas situa-se em relação aos textos a serem usados e a ênfase recai na compreensão, e não no ensino do código alfabético. Mas há menções explícitas a isso, e é nelas que se concentra o foco do presente trabalho.

0 Edital de 2008 (BRASIL, 2006, p. 55), afirma que

No quadro mais geral dessas preocupações relativas ao ensino da língua materna nas séries ou ciclos iniciais da educação fundamental é preciso atentar para as especificidades do processo de alfabetização. É extremamente importante que uma

4 As propostas de F. Smith $(1971,1973)$ foram baseadas em um único estudo em que crianças recebiam uma lista de palavras + texto ou apenas um texto, e se comparava qual das duas estratégias levaria à melhor compreensão. Suas conclusões foram imediatamente rebatidas com estudos usando diferentes textos. Mas isso não afetou a popularidade do autor. Os trabalhos de Emília Ferreiro foram baseados numa única pesquisa, com uma amostra de menos de 20 crianças, das quais a maioria era de classe média alta. Essas pesquisas nunca foram replicadas.

5 Os autores mais citados são Emília Ferreiro, Cesar Coll, Magda Soares e Mikhail Bakhtin. 
legítima preocupação com o letramento das crianças não se sobreponha a um trabalho sistemático com a alfabetização, vale dizer, com o domínio do sistema de escrita: de sua natureza e funcionamento, das relações entre o sistema fonológico do português e o sistema de escrita alfabético-ortográfico, das habilidades motoras e cognitivas envolvidas no uso de instrumentos e equipamentos da escrita. Não se pode esquecer que o domínio do domínio do sistema de escrita é uma das condições para o uso autônomo da língua escrita. Também não se pode esquecer que, pelo simples uso, desvinculado de uma atenção sistemática aos aspectos sonoros da língua, à exploração do sistema de escrita, dos processos de codificação e decodificação e ao desenvolvimento da fluência em leitura e da automatização do ato de escrever, a escola dificulta, e, muitas vezes, impossibilita a alfabetização das crianças.

Já no Edital de 2010 (BRASIL, 2008, p. 51-53) lemos que

nesse sentido recomenda-se que as coleções destinadas ao primeiro segmento do ensino fundamental organizemse de maneira a garantir que os livros destinados aos dois primeiros anos configurem-se como livros didáticos voltados para a alfabetização, focalizando, de um lado, as práticas de letramento necessárias ao (re)conhecimento da cultura letrada e ao exercício inicial das funções sociais da escrita; de outro, o domínio do sistema alfabético e, portanto, a compreensão de sua natureza e funcionamento. [...]

Nesse sentido, seja qual for sua opção didático-metodológica, o LDP não pode deixar de atender, sob pena de eliminação do PNLD 2010, a alguns requisitos teórico-metodológicos essenciais [...] no caso de o LPD recorrer a mais de um modelo didático-metodológico, justificar o arranjo proposto e indicar claramente a articulação entre seus componentes [...] relacionados ao letramento e à alfabetização que demandam, por sua natureza diversa, tratamentos didáticos específicos.

[...]

Nos critérios relativos à alfabetização: [...] a compreensão dos princípios que regulam a escrita alfabética, por meio de atividades de análise e reflexão sobre as propriedades sonora da fala e sua relação com os recursos gráficos da escrita; o desenvolvimento da fluência na leitura e na escrita.

Há mudanças sutis na forma de apresentação dessas ideias nos dois Editais. Em 2008 é mais forte a ênfase em sugerir atividades de alfabetização propriamente 
dita em relação a atividades de letramento. Em 2010, insiste-se mais em tratamentos didáticos específicos e se fala em fluência de leitura e escrita.

0 objetivo do presente trabalho é avaliar em que medida essas orientações, consistentes com o paradigma corrente da alfabetização - ainda que apresentadas de forma lacônica e no contexto de recomendações situadas e embasadas no paradigma de alfabetização predominante no Brasil - foram observadas nas cartilhas submetidas ao Fundo Nacional de Desenvolvimento da Educação (FNDE).

\section{Metodologia}

Foram analisadas as 19 cartilhas aprovadas pelo FNDE em 2009 e distribuídas às escolas públicas a partir de 2010. As cartilhas são apresentadas na versão do aluno e na versão do professor. A versão do professor inclui orientações inseridas no texto do aluno e um Manual do Professor. Utilizamos a versão das cartilhas que incluem o Manual do Professor ${ }^{6}$. Com base numa revisão da literatura científica sobre alfabetização, formulamos três perguntas: (1) se a proposta das cartilhas leva em consideração as evidências científicas sobre alfabetização, (2) se a proposta das cartiIhas leva em consideração as exigências estabelecidas no edital do PNLD com relação à decodificação (relação grafema/fonema) e fluência de leitura e (3) se o Manual do Professor complementa as cartilhas de forma a viabilizar a implementação de um processo eficaz de alfabetização.

Com base na revisão da literatura e numa análise preliminar de cada cartilha, elaboramos uma grade de referência para identificar a presença e incidência, nas cartilhas, dos componentes mais relevantes do processo de alfabetização. Como a maioria das cartilhas apresenta uma estrutura uniforme, em que cada lição apresenta grupos de atividades bastante semelhantes, escolhemos uma lição - normalmente a terceira lição, como base para análise. Cada cartilha foi examinada por dois dos três avaliadores que participaram do trabalho de análise. Em caso de discordância quanto ao critério, a análise foi revista conjuntamente pelos três autores, até se atingir o consenso.

Além da quantificação dos dados, compilamos as referências bibliográficas mencionadas pelos autores das cartilhas e analisamos as orientações constantes do Manual do Professor, com o objetivo de identificar outros aspectos relevantes para a presente análise, especialmente a definição de alfabetização adotada e a presença de orientações para o professor que poderiam contribuir para compensar eventuais lacunas presentes nas cartilhas.

6 Como as cartilhas não se encontram disponíveis nas livrarias, contamos com a colaboração pessoal do Dr. Henrique Paim, Secretário Executivo do MEC, que nos forneceu um exemplar das cartilhas. Enumeramos as cartilhas por ordem alfabética de editoras. As cartilhas citadas no presente trabalho foram numeradas aleatoriamente de 1 a 19 e não poderão ser identificadas por título ou autor. A ordem de apresentação das cartilhas no Anexo A obedece a outro critério. 


\section{Resultados}

\section{Concepção de alfabetização}

A concepção de alfabetização das cartilhas pode ser detectada pela análise tanto das cartilhas quanto do texto de fundamentação incluído nas páginas iniciais do Manual do Professor. Tipicamente esses textos repetem o que se encontra nos PCNs ou nas publicações do curso "Proletramento" e se ressentem da mesma falta de clareza e ambiguidade e das inconsistências características desses dois documentos ${ }^{7}$. Vejamos alguns exemplos dessas citações:

Essa proposta orienta-se em diferentes situações que envolvem a língua oral e a língua escrita de forma mais geral. Nesse sentido, apresentamos algumas formas de reflexão, observação e sistematização do trabalho com a linguagem, levando-se em constatação tanto as convenções relativas à direção da escrita e as diferenças existentes em relação ao registro das letras, quanto à construção de algumas regras ortográficas e o trabalho de sistematização que deve estar presente no processo inicial de alfabetização (MIRANDA; RODRIGUES, 2009, p. 4).

Entendemos que o trabalho com a alfabetização implica uma perspectiva mais ampla - a do letramento. Entendemos que o termo "alfabetização" refere-se fundamentalmente ao campo da Pedagogia, uma vez que diz respeito à ação de alfabetizar, e, portanto, ao processo escolar de ensino e de aprendizagem da leitura e da escrita, o que significa dizer, que, de um lado, esse processo sinaliza para diferentes formas de ensinar, e, de outro, para diferentes modos de aprender. [...] Assim entendemos o letramento como um modo de proceder diante da leitura e da escrita, ou seja, o estado ou a condição do sujeito que se utiliza dessas habilidades em diferentes circunstâncias práticas e diante de demandas sociais e culturais (MIRANDA; RODRIGUES, 2009, p. 7).

Sobre essa questão (alfabetizar letrando) Magda Soares esclarece: 'letramento é o estado ou condição de quem não só sabe ler e escrever, mas exerce as práticas sociais de escrita que circulam na sociedade em que vive, conjugando-as com as práticas de interação oral [...]'. Os mesmos autores afirmam que "ler é compreender (MIRANDA; RODRIGUES, 2009. p. 7).

Depois de apresentar os quatro estágios de Emilia Ferreiro (1989), os autores citam Adams a respeito da importância de ensinar a associar sons e letras:

7 Esse tema será aprofundado no capítulo de discussão. 
já que a noção de que a linguagem falada é composta de pequenos sons não surge de forma natural ou fácil com seres humanos' e cita novamente os textos do Proletramento sobre os objetivos a serem alcançados nos anos iniciais, entre os quais se incluem "dominar as relações grafemas e fonemas (incluindo as regularidades e irregularidades ortográficas (CARVALHO et al., 2009, p. 7).

Na mesma linha de raciocínio, lemos no Manual do Professor da Cartilha 3 (ESPI; ARAÚJ0, 2009, p. 7):

Assim, o termo alfabetização passou a designar não só a capacidade de codificar e decodificar, mas também o domínio de outros conhecimentos que possibilitam o uso da escrita em práticas sociais. [...] Muitos pesquisadores passaram então a utilizar o termo alfabetização para designar restritamente o aprendizado inicial da natureza e do funcionamento do sistema de escrita, reservando o termo letramento para designar os usos da língua escrita.

E citando o documento do Proletramento (BATISTA, 2006, p. 13 apud ESPI; ARAÚJ0, 2009, p. 7):

A leitura é um processo no qual o leitor realiza um trabalho ativo de construção do significado do texto [...] não se trata simplesmente de extrair informação da escrita, decodificando-a letra por letra, palavra por palavra. Trata-se de uma atividade que implica, necessariamente, compreensão na qual os sentidos começam a ser constituídos antes da leitura propriamente dita [...].

E continua:

As pesquisas desenvolvidas em situações reais de aprendizagem comprovam que se aprende a ler lendo. A ideia de que primeiramente o aluno deve aprender o nome e o valor sonoro das letras para, posteriormente, fazer a leitura de um texto deve, portanto, ser abolida. Desde os primeiros anos de escolarização, a criança deve ter acesso ao texto para poder ler, pois construirá esse novo conhecimento em atos de leitura significativa. Daí a necessidade de, mesmo antes de as crianças saberem ler, oferecer a elas textos autênticos diversificados e de boa qualidade. Isso permitirá uma iniciação satisfatória no processo de aprendizagem da leitura. Para tanto, o trabalho deve ser pautado a partir dos gêneros textuais[...] (ESPI; ARAÚJ0, 2009, p. 7-8). 
Mais adiante, a respeito da aprendizagem da escrita:

Aprender a escrever não é, como acreditava a tradição escolar, uma conquista mecânica. Pesquisas provaram que a criança aprende em situações reais do uso da escrita. Por isso, no primeiro ano de escolarização, o educador-alfabetizador deve proporcionar aos alunos atividades de escrita contextualizada em seus mais variados usos. Não é necessário que a criança, primeiramente, conheça o nome das letras e o valor sonoro representado por elas para, posteriormente, produzir textos escritos. Conhecer o nome das letras e o valor sonoro convencional delas é necessário para poder grafar textos convencionalmente, de modo que possam ser lidos e compreendidos por seus destinatários. Porém, o processo de reconstrução do sistema de escrita vai além desse domínio (ESPI; ARAÚJO, 2009, p. 7-8).

E continua, citando os PCNs (BRASIL, 1997, p. 33 apud ESPI; ARAÚJO, 2009, p. 7)):

A compreensão atual entre a aquisição da capacidade de redigir e grafar rompe com a crença arraigada de que o domínio do bé-á-bá seja pré-requisito para o início do ensino da língua e nos mostra que esses dois processos de aprendizagem podem e deve ocorrer de forma simultânea [...].

E conclui:

as atividades devem ser, portanto, planejadas de modo que a criança seja instigada a escrever mesmo sem grafar convencionalmente. Para isso, os conhecimentos prévios que possui acerca da escrita serão valiosos para a formulação de suas hipóteses (BRASIL, 1997, p. 9 apud ESPI; ARAÚJO, 2009, p. 7).

Semelhante é a abordagem do autor da Cartilha 4 (MIRANDA; PRESTA, 2009, p. 4-5):

Partimos da premissa que aprender a escrever não é simplesmente aprender a codificar sons em sinais gráficos, assim como aprender a ler não é simplesmente decodificar sinais gráficos em sons. Aprender a ler e a escrever significa compreender as leis internas que organizam cada um desses sistemas em particular. [....] Para compreender o sistema de escrita, a criança precisa usar diferentes recursos. Inicialmente, apoiar-se em palavras cujo sentido conheça e cuja escrita saiba de memória possibilita que, com base 
nelas, estabeleça relações e escreva novas palavras. Por exemplo 'como escrevo caminho? Ah! É com o ca de Camila!". "Como termina natal? Ah! é como Juvenal"8.

Nem todos os autores se sentem confortáveis com essas definições, e tentam conciliá-las com definições mais convencionais. Por exemplo, na Cartilha 5 (CEREJA; MAGALHÃES, 2009, p. 5-6):

Sabemos hoje que a alfabetização é um processo de construção conceitual, apoiado na reflexão sobre as características e o funcionamento da escrita, de modo que o alfabetizando compreenda as regularidades que caracterizam o sistema. Nesse enfoque, as atividades são construídas para o aluno desenvolver a capacidade de comparar, estabelecer relações, refletir, inferir, processar e compreender informações. Enfim, construir conhecimento. Sendo um processo de construção de hipóteses sobre o funcionamento e as regras do sistema alfabético de escrita, não será importante memorizar as famílias silábicas.

0 mesmo autor logo em seguida continua:

Segundo Costa Val [citação referente a um site] 'pode-se definir a alfabetização como o processo específico e indispensável de apropriação do sistema de escrita, pela conquista dos princípios alfabético e ortográfico que possibilitam ao aluno ler e escrever com autonomia. Noutras palavras, alfabetização diz respeito à compreensão e ao domínio do chamado código escrito, que se organiza em torno das relações entre a pauta sonora da fala e as letras (e outras convenções) usadas para representá-la na escrita (CEREJA; MAGALHÃES, 2009, p. 6).

0 autor continua com citações sobre a psicogênese da escrita, mas parece confundir o sistema alfabético com o sistema silábico:

Por exemplo, ao ouvir ou falar a palavra boneca, (o aluno) deve perceber que esta palavra é formada de três partes; que cada parte é constituída de determinados sons que, na escrita, devem ser representados por suas letras, independentemente de saber a palavra ou saber que quais letras a forma. Tal capacidade

8 Trata-se de uma teoria que postula que o aluno é capaz de inferir o funcionamento do código por analogia. Essa teoria é refutada por estudos empíricos citados no livro de Dehaene (2007), que compara sujeitos aprendendo um código artificial vs. uma lista de palavras. 0 grupo que aprendeu o código foi muito mais eficaz para aprender novas palavras. 
é construida a partir de atividades que estimulam a identificação tanto dos sons das palavras faladas/ouvidas, quanto das letras que representam esses sons.... Enquanto discrimina sons e letras, 0 alfabetizando aprende o traçado das letras e escrita das palavras [...] (CEREJA; MAGALHÃES, 2009, p. 22).

Essas citações dos vários autores sugerem o reconhecimento de que o conceito de alfabetização envolve o domínio do código alfabético. Ao mesmo tempo permitem observar que, em nenhuma delas a decodificação é considerada como o elemento principal do conceito de alfabetização. 0 foco principal é o "letramento", a compreensão do texto. É corrente, nas várias citações, o uso de expressões como "alfabetização é", "é também", "não é apenas", e todas elas têm como função reduzir a centralidade dos componentes que, de acordo com a Ciência Cognitiva da Leitura, seriam os aspectos centrais do conceito de alfabetização.

\section{Processo e métodos de alfabetização}

Já a concepção do processo de alfabetização goza de unanimidade: praticamente todas as cartilhas adotam, implícita ou explicitamente, a teoria de estágios de alfabetização postulados por Emilia Ferreiro, sempre se referindo às publicações do Ministério da Educação: escrita pré-silábica, silábica, silábica-alfabética e alfabética. A ideia subjacente à teoria de estágios, analogamente à teoria de estágios de desenvolvimento propostos por Jean Piaget, é que se trata de estágios naturais, que são conquistados pelas crianças à medida que testam suas hipóteses sobre o funcionamento do código ${ }^{9}$.

0 conceito de alfabetização e de seu processo apresentado na maioria das cartiIhas ajuda a entender o fato de que nenhuma das cartilhas trata da questão de métodos de alfabetização. Quando a questão é tratada, ela o é de forma ambígua, como, por exemplo, na frequente citação de um trecho de Magda Soares (2004, p. 13):

[...] no quadro dessa concepção (alfabetização e letramento) não há um método para a aprendizagem da língua escrita, há múltiplos métodos, pois a natureza de cada faceta determina certos procedimentos de ensino, além de as características de cada grupo de crianças, e até de cada criança, exigir formas diferenciadas de ação pedagógica.

Essa concepção também explica, como veremos adiante, a ausência de referências aos fonemas e à própria palavra fonema. Nessa concepção, os fonemas devem ser descobertos pelo aluno, por dedução, de maneira acidental, e em função de sua

9 Essa teoria foi proposta na primeira edição do livro A psicogênese da língua escrita. Apesar da popularidade dessa teoria, no Brasil, não existe, na literatura científica, evidências a respeito da validação de suas propostas, nem comprovação a respeito da existência da teoria de fases silábica, présilábica, etc. Ao contrário, a teoria de estágios proposta por Emilia Ferreiro foi refutada por vários estudos (ADAMS, 1990) e há mais de 20 anos ela não aparece referenciada em publicações em nenhuma das 20 principais revistas cientificas que tratam do tema. 
exposição a textos autênticos. É curioso observar que na única cartilha em que o assunto é abordado, o autor afirma que o trabalho de relacionar grafemas e fonemas não é abordado porque os professores fazem isso na prática ${ }^{10}$.

As demais cartilhas se limitam a reproduzir verbatim, orientações contidas nos PCNs (BRASIL, 1997, p. 18) como, por exemplo:

a aprendizagem deixa de estar centrada nos processos de codificação e decodificação do sistema. De acordo com estudos e pesquisas recentes, 'aprender a ler' envolve decifrar o texto escrito e interpretar e compreender os textos de diferentes gêneros e 'aprender a escrever' envolve grafar 0 escrito, estabelecer a correspondência entre letra e som e produzir textos de diferentes gêneros.

Ou citações do tipo:

[...] para que a leitura e escrita possam ser objeto de leitura de mundo e transformação da realidade é preciso que as compreendamos como um objeto social por excelência e a alfabetização como a inserção da criança na cultura letrada, com sua variedade de textos. [...] Partimos da premissa de que aprender a escrever não é simplesmente aprender a codificar sons em sinais gráficos, assim como aprender a ler não é simplesmente decodificar sinais gráficos em sons. Aprender a ler e escrever significa compreender as leis internas que organizam cada um desses sistemas em particular.

Ou ainda:

Ler é mais do que decodificar mecanicamente o sistema de signos. Todo leitor, por meio de um processo constante de elaboração e verificação de previsões, ressignifica os sentidos do texto para poder compreendê-lo. Esse processo deve ser ensinado e, para realizá-lo, o aluno não precisa sequer saber ler, desde que a mediação de leitura aconteça por meio de diversas intervenções e estratégias, entre elas a oferta e o estímulo à reflexão sobre variadas linguagens, tanto verbais quanto não verbais (BRASIL, 1997, p. 18).

10 Num dos estudos que fundamentam o relatório Alfabetização Infantil, os novos caminhos (BRASIL, 2003), há um estudo que mostra que as faculdades que formam professores alfabetizadores não tratam desses temas há pelo menos 20 anos. Portanto, torna-se difícil entender como os professores, que nunca aprenderam esses conceitos e não encontram qualquer referência ao tema na literatura oficial possam se informar a respeito dessas práticas. 
E também: "as atividades de alfabetização, desse modo, constituem-se em um meio para o estabelecimento de relações entre diferentes convenções e códigos, e para a reflexão sobre estes nos processos das práticas discursivas e sociais".

De longe, os textos mais citados para justificar porque a questão de métodos de alfabetização é irrelevante são os de Magda Soares (2004, p. 8-9) e o de Batista (2006), dos quais extraimos alguns trechos:

[...], porém, a especificidade de cada um desses processos (alfabetização e letramento) [...] implica reconhecer as muitas facetas de um e de outro e, consequentemente a diversidade de métodos e procedimentos para ensino de um e de outro, uma vez que, no quadro desta concepção, não há um método para a aprendizagem inicial da língua escrita, há múltiplos métodos [...].

E ainda: [...] "não se trata de escolher entre alfabetizar e letrar: trata-se de alfabetizar letrando. [...] os alfabetizandos inevitavelmente formularão hipóteses sobre sua utilidade, seu funcionamento e sua configuração" (BATISTA, 2006, p. 13).

A bibliografia utilizada para fundamentar as cartilhas apresentadas encontra-se sintetizada nos Quadros 1 e 2.

\begin{tabular}{|l|c|c|}
\hline Categoria & Total de referências & \% do total \\
\hline 1. Literatura/gêneros/discurso & 50 & 18 \\
\hline 2. Compreensão de textos & 14 & 5 \\
\hline 3. Produção de textos & 3 & 1 \\
\hline 4. Linguística (geral) & 30 & 11 \\
\hline 5. Ling6istica (fonética) & 11 & 4 \\
\hline 6. Teorias/discurso sobre alfabetização & 34 & 12 \\
\hline 7. Ensino do código alfabético/decodificação & 5 & 2 \\
\hline 8. Assuntos gerais (sociologia, filosofia, etc.) & $66+14=80$ & 30 \\
\hline Total & 265 & \\
\hline
\end{tabular}

Quadro 1 - Bibliografia indicada nas Cartilhas analisadas.

Fonte: 0 autor (2010).

0 número de referências não pertinentes diretamente à alfabetização representa $30 \%$ do total de citações. Já o número de referências diretamente pertinentes aos aspectos centrais da alfabetização restringe-se a 5, ou seja, menos de $2 \%$ do total de citações. Por outro lado, os textos e discursos gerais sobre letramento e outras questões genéricas são 7 vezes mais abundantes. No campo da linguística, os estudos mais pertinentes ( 11 citações sobre fonética) são 3 vezes menos frequentes do que os menos pertinentes. 
0 Quadro 2 apresenta o nome dos autores e/ou das obras que foram citados mais de 5 vezes. 0 quadro é apresentado em duas colunas porque em alguns casos foram citadas obras diferentes de um mesmo autor, como é, inclusive, o caso de documentos do MEC.

\begin{tabular}{|l|l|}
\hline Autores citados mais de $\mathbf{5}$ vezes & Obras citadas mais de $\mathbf{5}$ vezes \\
\hline Bakhtin & - \\
\hline MEC & - \\
\hline Gagliari, Luis Carlos & Alfabetização e Linguistica \\
\hline Ferrero, Emilia & Com todas as letras \\
\hline Jolibert, J. et. al. & Formando crianças leitoras (vol. I e II) \\
\hline Kaufmann, A. M. et alia. & Alfabetização. Escola, leitura e produção de textos. \\
\hline Kleiman, Angela & - \\
\hline Lajolo, Marisa & - \\
\hline Lemle, Miriam & Guia teórico do alfabetizador \\
\hline Morais, A. G. & Ortografia: ensinar e aprender \\
\hline Rojo, Roxane & - \\
\hline Smolka, M.L.B & $\begin{array}{l}\text { A criança na fase inicial da escrita: a alfabetização } \\
\text { como processo discursivo }\end{array}$ \\
\hline Soares, Magda & Letramento: um tema em três gêneros \\
\hline Teberosky, A. & - \\
\hline Vigotsky, L. & - \\
\hline
\end{tabular}

Quadro 2 - Autores e obras mais citados nas cartilhas analisadas. Fonte: 0 autor (2010).

Dos autores citados, apenas Emilia Ferreiro (1989) possui estudos empíricos sobre alfabetização. Cagliari e Miriam Lemle são autores de estudos de linguística que trazem implicações para o entendimento do funcionamento do sistema alfabético de escrita. Os demais autores e obras ou não são fundamentados em evidências empíricas ou não tratam de questões diretamente relevantes ao ensino da leitura e escrita.

A análise das citações também mostra que poucos autores receberam mais de cinco citações. Apenas dois autores - Emilia Ferreiro e Ana Teberosky (1986) tiveram alguma de suas obras citadas por mais de 10 autores de cartilhas. Ou seja, embora haja um profundo consenso a respeito do entendimento do que seja alfabetização, as fontes e referências não apresentam muita superposição.

Cabe observar que nenhum dos autores citados nas publicações e relatórios internacionais mais relevantes sobre o tema publicados desde 1990 receberam qualquer citação. ${ }^{11}$

11 A única exceção é um manual de atividades de desenvolvimento de consciência fonológica de Adams. Trata-se de um manual de atividades, não de uma obra de caráter científico. E essa única citação é feita de forma inconsistente com o contexto em que está inserida 
Esses dados indicam que a concepção de alfabetização adotada pelos autores das cartilhas no Brasil é inteiramente consistente com as orientações gerais emanadas do MEC e com o espírito do Edital, e que, consequentemente, encontram-se à margem do paradigma científico predominante da Ciência Cognitiva da Leitura. Eles também permitirão antecipar que as orientações do edital a respeito de decodificação e fluência de leitura dificilmente serão atendidas. Com base nessas observações, é possível antecipar que as cartilhas deverão apresentar poucas das características listadas na grade de referência que será analisada nas próximas seções.

\section{A estrutura das cartilhas}

Do total das 19 cartilhas, 17 são organizadas de acordo com uma estrutura bem definida. A cartilha é dividida por Unidades. A Unidade quase sempre se refere a um assunto ou tema - o que é consistente com o objetivo principal, que é promover o letramento pela familiaridade com os gêneros textuais. Nas duas cartilhas que não seguem essa ordem, uma delas apresenta lições que têm como título as letras do alfabeto. A outra se limita a apresentar unidades sem uma característica distinta, mas também com ênfase na apresentação dos textos.

0 Quadro 3 apresenta a relação das cartilhas por número de Unidades, Lições, Atividades e Número de Páginas.

\begin{tabular}{|l|c|c|c|c|c|c|c|c|c|c|c|c|c|c|c|c|c|c|c|}
\hline & $\mathbf{1}$ & $\mathbf{2}$ & $\mathbf{3}$ & $\mathbf{4}$ & $\mathbf{5}$ & $\mathbf{6}$ & $\mathbf{7}$ & $\mathbf{8}$ & $\mathbf{9}$ & $\mathbf{1 0}$ & $\mathbf{1 1}$ & $\mathbf{1 2}$ & $\mathbf{1 3}$ & $\mathbf{1 4}$ & $\mathbf{1 5}$ & $\mathbf{1 6}$ & $\mathbf{1 7}$ & $\mathbf{1 8}$ & $\mathbf{1 9}$ \\
\hline Unidades & 8 & 4 & 4 & 8 & - & 8 & 4 & 10 & 12 & 3 & 4 & 5 & 4 & 2 & 5 & 4 & 5 & 10 & 8 \\
\hline Lições & 8 & 12 & 18 & 8 & 36 & 8 & 20 & 10 & 12 & 10 & 14 & - & 12 & 41 & 13 & - & 15 & 10 & 16 \\
\hline Atividades & 88 & 54 & 20 & 48 & 14 & 40 & 22 & 65 & 30 & 40 & 51 & 86 & 108 & 11 & 42 & 73 & 42 & 75 & 43 \\
\hline Páginas & 115 & 176 & 240 & 288 & 225 & 170 & 208 & 240 & 192 & 220 & 160 & 200 & 216 & 264 & 180 & 188 & 226 & 276 & 160 \\
\hline
\end{tabular}

Quadro 3 - Número de Unidades, Lições, Atividades e Páginas.

Fonte: 0 autor (2010).

\section{A estrutura didática das lições}

Para efeito do presente estudo, consideramos como unidade de análise as lições individuais, ou, no caso das cartilhas que não possuem lições, a estrutura didática da Unidade. Em 17 das 19 cartilhas as lições ou unidades seguem um mesmo padrão e uma mesma ordem para apresentar diferentes tipos de atividade. Normalmente há uma leitura, um bloco de atividades relacionado com a compreensão da leitura, atividades relacionadas com a escrita de palavras e atividades relacionadas com a produção de textos. Frequentemente há uma mistura de atividades de natureza diferente dentro de um mesmo bloco - isso é mais frequente do que raro. 0 tamanho das lições e o número de atividades de cada tipo também tende a ser bastante uniforme dentro de cada cartilha - mas a natureza e quantidade de atividades entre cartilhas variam muito, conforme se verá em análises subsequentes. 


\section{Ordem de apresentação dos grafemas e fonemas}

De acordo com as recomendações do NRPR, o domínio do princípio alfabético requer o conhecimento do alfabeto, isto é, reconhecer o nome e a forma das letras em suas diversas variantes (fonte, formato, maiúscula, minúscula, letra de forma ou cursiva). A evidência a respeito dos métodos mais eficazes de alfabetização preconiza que os grafemas devam ser apresentados de maneira sistemática e explícita, para que a criança possa abstrair o conceito de fonema a partir de exposições múltiplas.

Do total das 19 cartilhas, 18 apresentam o alfabeto e a ordem alfabética, nas páginas iniciais. 0 treino da ordem alfabética, ausente na maioria das cartilhas, quando aparece limita-se às duas primeiras lições. No que se refere à apresentação dos grafemas, apenas duas das 19 cartilhas apresentam todas as letras do alfabeto de maneira explícita, inclusive com lições dedicadas ao estudo de cada letra.

No que se refere aos fonemas, em nenhuma cartilha foi possivel identificar nem atividades relacionadas ao desenvolvimento de consciência fonológica - que tipicamente são atividades orais - nem atividades que, de maneira sistemática ou explícita, orientassem o professor ou o aluno para identificar fonemas correspondentes aos grafemas (letras) apresentados.

Algumas cartilhas têm a silaba como unidade. Aquelas que têm a letra como unidade não apresentam atividades que ajudem o aluno a identificar o seu valor sonoro, de maneira explícita e muito menos, de maneira sistemática. Algumas cartilhas apresentam, vez por outra, atividades em que o aluno deve identificar a primeira letra ou a letra comum a várias palavras. Em um caso uma cartilha apresenta um único tipo de atividade em que o aluno deve identificar uma letra (vogal) que torna várias palavras diferentes (lado, lido, lodo). Mas isso também é feito de forma incidental em uma ou duas lições. Apenas duas cartilhas mencionam a palavra "fonema" em seus manuais, e, em ambos os casos, citando documentos oficiais, e não para apresentá-los ou tratar de seu ensino.

\section{Caligrafia: a forma das letras}

Todas as 19 cartilhas apresentam as letras maiúsculas e possuem alguma atividade cuja ênfase é treinar a escrita de letras maiúsculas. As letras minúsculas são usadas raramente para apresentar textos e nunca são exigidas nas atividades. Nenhuma cartilha apresenta orientações ou atividades para o ensino formal da caligrafia. Apenas uma cartilha apresenta, incidentalmente, atividades de caligrafia. Em um dos 19 manuais aparece uma referência ao ensino de caligrafia, mas nenhuma orientação prática quanto ao seu ensino.

Uma das poucas menções ao tema se faz de forma casual, sem qualquer fundamentação científica: 
Uma das indagações recorrentes entre educadores-alfabetizadores é: qual é a melhor letra para alfabetizar: a cursiva ou a maiúscula? Na verdade, não existe uma regra ou uma única resposta. Há educadores que defendem a letra de forma maiúscula como a mais apropriada para ensinar leitura-eescrita e há os educadores que consideram a letra cursiva adequada a esse propósito. [...] Embora a discussão acerca do tipo de letra a ser introduzido no início da alfabetização seja fundamental, o mais importante nessa questão é estar atento ao fato de que aprender a escrever não é simplesmente aprender a grafar letras. Portanto, o empenho do professor deve ser o de mediar a reconstrução do código escrito por seus alunos (CEREJA; MAGALHÃES, 2009, p. 13-14).

\section{Decodificação e contextualização}

Um dos carros-chefe dos métodos globais e de inspiração construtivista é o conceito de contextualização: a aprendizagem da leitura (decodificação) deve ocorrer no contexto de situações autênticas de leitura, a partir de textos denominados "autênticos". 0 aluno aprende a decodificar elaborando hipóteses sobre o que leva uma palavra a ser escrita de uma ou outra forma. Como a palavra deve ser significativa para o aluno, as palavras escolhidas para decodificar devem ser contextualizadas. Portanto, cabe indagar em que medida as palavras usadas para atividades de decodificação estão relacionadas com o contexto da leitura.

Com efeito, 15 das 19 cartilhas usam palavras do texto ou o próprio texto para desenvolver atividades que implicam o reconhecimento de palavras, cópia de palavras, ou para identificar uma determinada letra (quase sempre a letra inicial) ou uma rima. Portanto, ainda que não haja um esforço sistemático para ensinar a ler, no sentido de ensinar a decodificar, há um esforço sistemático em relacionar as palavras usadas nas atividades com as palavras usadas no texto. Ou seja, há um esforço sistemático para contextualizar a aprendizagem das palavras ${ }^{12}$.

\section{Atividades para promover a decodificação}

De acordo com os princípios da Ciência Cognitiva da Leitura, um processo de alfabetização é mais eficaz quando a relação entre fonemas e grafemas é apresentada de maneira sistemática e explícita (ADAMS, 1990; MCGUINNESS, 2004, 2005). Sistemática significa apresentar os fonemas e respectivos grafemas, em uma determinada ordem. Explícita significa que os fonemas devem ser apresentados e associados com os grafemas, em diferentes posições da palavra - tipicamente 0 início, meio e final das palavras. 0 objetivo disso é triplo. De um lado, assegurar que o aluno conheça a valência de cada

12 Como o critério predominante é o do contexto e do significado, a escolha de palavras não leva em conta a especificidade do código alfabético, como seria recomendável de acordo com o NRPR. 
fonema da língua e sua relação com determinado grafema. 0 outro objetivo, mais importante, é que, a partir de associações explícitas entre fonemas e grafemas, a criança adquira o Princípio Alfabético, ou seja, a ideia de que há uma correspondência entre grafemas e fonemas. 0 terceiro objetivo refere-se à aprendizagem da decodificação. A decodificação é o primeiro passo para a leitura. Para decodificar o aluno precisa identificar as letras, identificar o fonema que elas representam, emitir os sons correspondentes aos fonemas necessários para pronunciar a palavra. Ao pronunciar a palavra TIA ou TUA a criança já modula a boca de forma a pronunciar o fonema /chi/ ou /t/, de acordo com a vogal subsequente. De acordo com as evidências empíricas, a apresentação sistemática e explícita de palavras cujos fonemas e grafemas são conhecidos é a forma mais eficaz para alfabetizar, pois dá total segurança ao aluno e elimina possiveis erros.

Os estudos realizados nos últimos 20 anos, em particular, sugerem que as palavras usadas para ensinar a decodificar não devem estar relacionadas ao contexto de compreensão (texto), e sim ao contexto do alfabeto, ou seja, em função de suas caracteristicas morfossintáticas. Perfetti (1985) conclui, a partir de seus estudos, que os bons leitores utilizam as palavras para ler e o contexto para compreender. Os maus leitores, que não dominam a decodificação, utilizam o contexto para ler, e acabam prejudicados tanto na leitura quanto na compreensão. 0 procedimento recomendável é só utilizar palavras que o aluno consiga decodificar, portanto, as palavras devem ser apresentadas a partir de uma determinada sequência de palavras "decodificáveis". Isso permite ao aluno aplicar sempre a regra da decodificação de maneira consistente. 0 outro critério para escolha das palavras refere-se ao tamanho e tipo de silabas. Estudos empíricos sobre os efeitos da regularidade e complexidade silábica mostram que a aprendizagem da alfabetização se dá do simples para o complexo, das silabas mais simples ( $C V, C V C V, C V C$, até as mais dificeis, como as que contêm encontros consonantais e dígrafos ${ }^{13}$. Portanto, de acordo com a evidência empírica, o modo como o cérebro aprende a ler sugere que os critérios para escolha das palavras usadas para decodificar não devem estar relacionados com o texto ou o contexto, mas com a estrutura morfossintática das palavras (SPRENGER-CHAROLLES; SIEGEL, 1997; SPRENGER-CHAROLLES; SIEGEL; BONNET, 1998).

A análise das 19 cartilhas revela que nenhuma delas leva em conta essa recomendação. Há vários exercícios que podem ser considerados de decodificação nessas cartilhas, mas o trabalho de decodificar é entendido como o trabalho de reinventar, "construir hipóteses" sobre o funcionamento do código, e não o de utilizar as regras do código para ler a palavra. É por isso que os exercícios propostos para decodificação nas cartilhas não levam em conta grafemas ou fonemas já aprendidos. E também não existem atividades para ensinar as duas técnicas mais eficazes para aprender a decodificar, a análise e sintese de fonemas (ADAMS, 1990; JOHNSTON, R.; WATSON, 2005).

13 Uma das implicações práticas dessa dificuldade é que quanto mais cedo se ensinam essas dificuldades, mais tempo e treino o aluno terá para dominá-las. Isso, no entanto, não exclui atenção à ordem em que os grafemas devem ser apresentados, de forma a assegurar que o aluno seja capaz de decodificá-los. 
$\mathrm{Na}$ verdade, as cartilhas partem do pressuposto de que os alunos aprendem, de alguma forma, o princípio alfabético e as regras da decodificação, e partem, diretamente, para o ensino do código ortográfico. Com relação à apresentação e ensino de dígrafos, apenas três cartilhas tratam do assunto, também de forma assistemática.

\section{Em que consistem as atividades das cartilhas}

Conforme já apresentado no Quadro 3, o número de atividades varia muito nas diferentes cartilhas. Definimos como atividade qualquer ação que implica uma resposta explícita pelos alunos. 0 número de atividades varia de 11 a 108. A maioria das cartilhas apresenta entre 40 e 70 atividades por lição.

As atividades podem exigir uma resposta escrita ou verbal, individual, em dupla ou grupal. A maioria das atividades, no entanto, requer algum tipo de resposta individual escrita. Em duas cartilhas há a recomendação explícita, nas lições iniciais, para que o trabalho seja feito oralmente, já que o aluno ainda não consegue ler nem escrever. Nas demais cartilhas - consistente com os pressupostos teóricos das cartilhas - 0 aluno é encorajado a ler e escrever do seu jeito. 0 Quadro 4 apresenta 0 total e porcentagem das atividades apresentadas numa lição típica das cartilhas:

\begin{tabular}{|c|c|c|c|c|c|c|c|c|c|}
\hline$N$ & $\begin{array}{l}\text { Total de } \\
\text { atividades }\end{array}$ & $\begin{array}{l}\text { Decodificação } \\
\text { Total }\end{array}$ & $\begin{array}{l}\text { Decodificação } \\
\%\end{array}$ & $\begin{array}{l}\text { Voc. e. } \\
\text { Compr. }\end{array}$ & $\%$ & \begin{tabular}{l|l} 
Outras \\
atividades
\end{tabular} & $\%$ & \begin{tabular}{|l|} 
Atividades \\
Não \\
pertinentes
\end{tabular} & $\%$ \\
\hline 1 & 88 & 2 & 2.2 & $17+19$ & 40.0 & 49 & & 6 & 6.8 \\
\hline 2 & 54 & - & - & $2+20$ & 40.0 & 31 & & 1 & 1.8 \\
\hline 3 & 20 & 2 & 10.0 & $3+3$ & 30.0 & 12 & & - & - \\
\hline 4 & 48 & - & - & $7+36$ & 93.0 & 6 & & - & - \\
\hline 5 & 14 & - & - & $3+5$ & 43.0 & 5 & & - & - \\
\hline 6 & 40 & 3 & 7.5 & $4+0$ & 10.0 & 29 & & 2 & 5.0 \\
\hline 7 & 22 & - & - & $11+13$ & 37.0 & 11 & & - & - \\
\hline 8 & 65 & 3 & 4.6 & $11+13$ & 37.0 & 37 & & - & - \\
\hline 9 & 30 & 1 & 3.3 & $10+10$ & 67.0 & 9 & & - & - \\
\hline 10 & 40 & - & - & $2+10$ & 35.0 & 26 & & - & - \\
\hline 11 & 51 & - & - & $9+14$ & 45.0 & 19 & & 7 & 13.7 \\
\hline 12 & 86 & 10 & 11.6 & $2+31$ & 38.5 & 20 & & 18 & 20.9 \\
\hline 13 & 108 & - & - & $2+50$ & 48.0 & 41 & & 13 & 12.0 \\
\hline 14 & 11 & - & - & $6+1$ & 33.0 & 1 & & 3 & 27.2 \\
\hline 15 & 42 & - & - & $4+21$ & 60.0 & 4 & & 12 & 28.6 \\
\hline 16 & 73 & - & - & $4+33$ & 50.7 & 24 & & 10 & 13.7 \\
\hline 17 & 42 & - & - & $6+19$ & 48.2 & 1 & & 16 & 37.2 \\
\hline 18 & 75 & 2 & 2.6 & $4+37$ & 55.0 & 22 & & 3 & 4.0 \\
\hline 19 & 43 & - & - & $2+4$ & 14.0 & 29 & & 4 & 9.3 \\
\hline Total & 952 & 23 & 0,02 & 358 & 37.5 & 348 & 36.5 & 95 & 10 \\
\hline
\end{tabular}

Quadro 4 - Principais tipos de atividades nas cartilhas.

Fonte: 0 autor (2010). 
0 Quadro 4 mostra que a decodificação é o alvo do menor número de atividades, representam $1 / 5$ de $1 \%$ do total. As atividades não relevantes à alfabetização (ou letramento) representam 20 vezes mais, cerca de $10 \%$ do total de atividades. Por outro lado, as atividades voltadas para o desenvolvimento do vocabulário e compreensão representam $37,5 \%$ do total. Outras atividades, que representam $36,5 \%$ do total, referem-se, sobretudo, a atividades de produção de textos, e apenas uma pequena parte dessas atividades refere-se à ortografia ou caligrafia. Conforme registrado no Quadro 4, 0 número de "outras" atividades é relativamente grande, e, em todos os casos, superior ao número de atividades voltadas para as atividades centrais da alfabetização.

Quando separamos outras atividades pertinentes e não pertinentes, observamos que mesmo as atividades não pertinentes ao processo de alfabetização ocupam mais espaço e merecem mais atenção do que as atividades que, segundo o NRPR, deveriam ocupar o tempo maior no processo de alfabetização. Essas atividades quase sempre envolvem recreação, atividades lúdicas sem objetivos definidos ou atividades que envolvem números, e formas.

Quanto às "outras" atividades pertinentes, elas são relativamente numerosas. Parte delas refere-se a atividades relacionadas ao código alfabético: desenhos nos quais a criança deve escrever o nome da palavra, caça-palavras para identificar palavras com determinadas características e sílabas para montar palavras. Como já observado anteriormente, essas atividades são consistentes com a ideia de que a criança deve redescobrir o código (fazer hipóteses), mas não são o mesmo que ensinar a decodificar. Há também letras móveis para trabalho com os grafemas, mas raramente aparecem orientações sobre o que fazer com elas. As demais "outras" atividades referem-se àquelas relacionadas com ortografia, e, na sua imensa maioria, com a produção de textos. Embora a criança ainda não seja capaz de escrever, a maioria dessas atividades requer o registro escrito das "produções textuais" da criança. Não encontramos nenhuma atividade referente ao desenvolvimento de consciência fonológica ou de fluência de leitura ${ }^{14}$. Nas seções seguintes analisamos os dados referentes às atividades diretamente voltadas à alfabetização.

\section{Atividades relacionadas com alfabetização propriamente dita}

De acordo com o NRPR, as atividades centrais relacionadas com alfabetização incluem atividades de consciência fonológica, princípio alfabético e fluência de leitura. Essas atividades - junto com o domínio da caligrafia - deveriam consumir, portanto, a maior parte do tempo da aprendizagem da leitura e da escrita.

14 Atividades de consciência fonológica são atividades orais, começando pela segmentação de palavras e identificação de rimas. Identificar rimas em textos escritos não configura atividades de desenvolvimento de consciência fonológica, pois já pressupõem a capacidade de leitura. 
Como se observa do Quadro 4, as atividades voltadas para competências de alfabetização são ínfimas e aparecem em apenas sete das 19 cartilhas. As próximas seções esclarecem melhor a questão.

\section{Atividades de decodificação}

Decodificar significa compreender as regras de funcionamento do código alfabético e usá-las para ler e escrever as palavras. Atividades de decodificação têm como objetivo ajudar o aluno a compreender o código alfabético e, usando esse conhecimento, ler ou escrever uma palavra. Por exemplo, se o aluno sabe que as letras $A$ e $U$ correspondem aos fonemas /a/ e / $u /$ ele pode ler as palavras $A u$ ou Uau, ou as pseudopalavras UA, AUA, AUAU ${ }^{15}$. Se ele sabe que a valência da letra $L$ é /I/ e conhece o valor fonético das vogais, ele pode ler palavras como ala, ela, lua, lia, leia, etc. Há vários tipos de exercícios usados para ensinar a decodificar, e eles podem ser tanto orais quanto escritos. Normalmente os exercícios orais incluem a identificação do fonema no início, meio e fim da palavra, e, posteriormente, atividades de análise (decompor uma palavra nos seus fonemas) ou sintese (compor uma palavra a partir de fonemas orais ou de letras escritas). Para que o aluno possa decodificar uma palavra, ele deve conhecer todas as letras e pelo menos um fonema associado a elas. Essas são chamadas palavras decodificáveis.

0 Quadro 4 permite observar que, mesmo nas cartilhas em que há algum tipo de atividade de decodificação, essas atividades consideradas essenciais para promover a alfabetização representam entre 2,0\% e 7,5\% das atividades das cartilhas. Em 12 das 19 cartilhas não há qualquer atividade desse tipo. E onde as há, tipicamente as atividades se concentram em identificar o fonema correspondente à letra inicial das palavras. Há pouquíssimos casos de atividades envolvendo fonemas no meio ou no final da palavra. Mesmo quando existem tais atividades, elas não se apresentam de forma consistente. Por exemplo, numa lição sobre fonemas nasais, o aluno deve identificar a letra $\mathrm{N}$ no meio de uma palavra. Inexistem atividades de sintese fonêmica - a técnica considerada mais eficaz para alfabetizar (JOHNSTON; WATSON, 2005).

\section{Fluência de leitura e pseudopalavras}

Fluência de leitura é a ponte que liga a decodificação com a compreensão. No processo de aprendizagem da leitura a criança aprende - ao mesmo tempo, mas com intensidades diferentes - a decodificar, a identificar automaticamente algumas palavras e, aos poucos, a emendar a leitura de palavras em frases, e de frases num parágrafo.

15 Usamos a notação simplificada de fonemas / /, dado o fato de que a maioria dos leitores não conhece as regras da notação técnica apresentada em livros de fonética. 
A identificação automática de palavras se dá de duas formas. Uma delas é pela leitura global da palavra. Qualquer criança conhece a palavra Coca Cola e talvez uma dezena de outras. As palavras são lidas como desenho. Normalmente são palavras de uso frequente. Essa forma de pseudoleitura, que mais se aproxima da adivinhação, mobiliza o sistema visual do cérebro, na região occipitotemporal direita, diferentemente do que ocorre posteriormente, durante o processo de alfabetização. A criança identifica apenas algumas caracteristicas visuais da palavra, sem demonstrar qualquer capacidade para decodificá-la ${ }^{16}$.

A outra forma também se dá pela associação: a criança aprendeu a decodificar uma palavra, encontra essa palavra com frequência em atividades escritas e, pela repetição, memoriza a forma visual da palavra. A capacidade de identificação automática de palavras se mede pela rapidez de reconhecimento e pela capacidade de decodificar, ou seja, a criança que ainda não consegue ler uma palavra imediatamente deve ser capaz de decodificar a palavra, se tiver tempo para tanto. Isso é diferente de memorizar a forma visual da palavra - a criança que memoriza Coca Cola lê Dola Tola como se fosse Coca Cola. A decodificação, portanto, constitui o primeiro passo do processo de aquisição de fluência de leitura, que é o reconhecimento automático de palavras. Nesse estágio a leitura passa a ativar, de maneira predominante, a região occipitotemporal esquerda e as regiões temporais laterais.

Para avaliar a efetiva capacidade de decodificação, portanto, não basta apresentar uma lista de palavras para a criança - pois ela poderia ler com base na memória visual. Para isso, é essencial usar a técnica de leitura de pseudopalavras. Pseudopalavras são palavras que obedecem às regras fonotáticas de uma língua, mas que não possuem sentido próprio. A palavra "bafana" ou a frase "A tonga da mironga do cabuletê" são exemplos. Somente uma criança que sabe decodificar é capaz de ler essas palavras. Este é o único teste capaz de avaliar, efetivamente, se a criança domina as regras do código alfabético. A leitura de pseudopalavras também demonstra que ler e compreender são atividades totalmente separadas, do ponto de vista neurobiológico e da aprendizagem ${ }^{17}$.

Em nenhuma das 19 cartilhas há qualquer atividade relacionada com o desenvolvimento da fluência de leitura nem qualquer menção, nas cartilhas ou manuais do professor, a respeito do conceito ou uso didático de pseudopalavras. Vale lembrar que o Edital do PNLD enfatiza, de maneira explícita, que as cartilhas deveriam incluir atividades de fluência de leitura.

16 Por essa razão é possível afirmar, com base nas conclusões de Dehaene (2007, p. 274-175) que os métodos globais são prejudiciais à aprendizagem, pois reforçam uma área do cérebro que não é a área ótima para processar as informações necessárias para uma leitura fluente.

17 Os estudos sobre imagens cerebrais mostram que os dados sobre a forma visual das palavras são armazenados em regiões do cérebro e utilizam redes neuronais do cérebro diferentes das regiões e redes que tratam da semântica. Ensinar a ler significa ensinar o cérebro a desenvolver essas conexões e a articular esses dois niveis - inteiramente distintos - de competências. 


\section{A pedagogia das cartilhas}

As cartilhas são elaboradas de forma estruturada e consistente com as teorias que a elas são subjacentes. Há uma estrutura para as Unidades e uma estrutura para as lições. Cabe indagar como os alunos podem "navegar" diante do texto. Para tanto, examinamos os comandos para saber (1) se o aluno é capaz de ler o que é pedido, com base no que foi ensinado, e (2) se o aluno é capaz de escrever o que foi pedido, com base no que foi ensinado.

A resposta a ambas as perguntas, válida para as 19 cartilhas, é negativa. Isso se deve à concepção das cartilhas: elas são feitas para serem lidas pelo professor. $E$ as respostas devem ser dadas "com a ajuda" do professor - pelo menos até que o aluno descubra o funcionamento do código alfabético e aprenda a escrever.

Crianças que ainda não aprenderam a ler não são capazes nem de ler textos nem de ler os comandos dos exercícios. Esta é a razão pela qual o NRPR e autores como Rhona Johnston recomendam que o trabalho com a decodificação seja centrado em palavras relativas a determinados grupos de fonemas, e não em textos. Em relação aos comandos, uma estratégia usual para lidar com alunos não leitores consiste no uso de ícones, que permitem ao aluno identificar o tipo de atividade que se espera deles. Mas esta abordagem não é a utilizada nas cartilhas - todos os comandos devem ser lidos pelo professor.

A concepção pedagógica que preside a elaboração de cartilhas não induz a esses procedimentos. Com isso, todo o trabalho de leitura de textos e comandos fica dependente da iniciativa do professor. Ou, como ocorre em várias cartilhas, 0 aluno é incentivado a usar pistas contextuais para "descobrir" o que está escrito. Um exemplo típico: pede-se ao aluno, já nas primeiras lições, que identifique o título, o nome do autor, etc. É comum, nas cartilhas existentes, que já na segunda ou terceira lição o aluno seja convidado a identificar palavras que representam o nome de frutas ou objetos escolares no texto. Para fazer isso, o aluno deve utilizar um processo de aproximações sucessivas, ou seja, lembrar-se do nome de um objeto que foi lido (lápis, por exemplo), descobrir que a palavra lápis começa com a letra $L, e$, com esses conhecimentos, procurar palavras que comecem com a letra. A partir daí, possivelmente usando uma estratégia de adivinhação, o aluno poderá dizer que tal palavra é lápis. Em muitas cartilhas pede-se ao aluno para identificar três ou quatro palavras de uma vez - três substantivos ou adjetivos. Trata-se do entendimento da alfabetização como "um jogo psicolinguístico de adivinhação" proposto por Smith nos anos 60.

0 mesmo ocorre com as demandas referentes às respostas escritas. Por exemplo, é muito usual nas cartilhas pedir para o aluno escrever o nome de outros colegas que começam com uma determinada letra. Para realizar tal ta- 
refa, o aluno pode recorrer a duas estratégias. A primeira dela é copiar o nome do colega a partir de uma lista existente em algum lugar da sala. Ou desenhá-lo, se já souber a forma visual da palavra correspondente a esse nome. Isso não envolve processos de decodificação. A outra estratégia consiste em "fazer hipóteses" e completar o nome com grafemas que, a seu ver, correspondem aos sons que constituem o nome de seu colega. Praticamente todas as atividades escritas que são solicitadas nas cartilhas exigem do aluno uma competência que não foi ensinada - a capacidade de reproduzir, por escrito, o som de uma palavra que ele ouviu ou inferiu a partir de um comando (nome de frutas ou características de uma pessoa, por exemplo). Em nenhuma das cartilhas analisadas, mesmo nas lições iniciais, o aluno possui as ferramentas para escrever, com autonomia, a palavra, palavras ou frases que the são solicitadas.

Ou seja, embora, no discurso teórico, os autores reconheçam a importância, ainda que limitada da decodificação, na prática os métodos utilizados incentivam o uso de outras estratégias - e especialmente o uso de pistas contextuais e da adivinhação, para identificar palavras. A estratégia pedagógica usada nas cartilhas é inteiramente consistente com a concepção de alfabetização e ensino da leitura e escrita constante dos PCNs e dos estudos mais citados pelos autores das cartilhas. E diametralmente oposta às conclusões da Ciência Cognitiva da Leitura.

\section{O Manual do professor}

Analisamos os Manuais do Professor para identificar informações adicionais que permitiriam ao professor ensinar o aluno a decodificar. Mas os Manuais não tratam disso, da mesma forma que não tratam de métodos de alfabetização, de técnicas de análise ou sintese de fonemas ou de letras nem de pseudopalavras. Três das 19 cartilhas mencionam que o professor deve utilizar as oportunidades de trabalho com as palavras para ajudar as crianças a identificar os fonemas, sem entrar em maiores especificações. E um Manual diz que como os professores são habituados ao trabalho de mostrar as relações fonema-grafema, este assunto não precisava ser abordado nem no Manual nem na cartilha:

Essa proposta aparece nas três primeiras unidades do livro e visa a sistematização e memorização das crianças em relação às letras, seus nomes, seus sons, seus diferentes formatos, incluindo a letra cursiva. Essa sistematização, geralmente, já é feita pelos professores em sala de aula sem o apoio do livro didático, por isso assumimos essa atividade, que a maioria dos professores considera essencial e cujo aprofundamento e possibilidade de extrapolação dependerá do conhecimento que as crianças já possuem sobre as letras do alfabeto (ESPI; ARAÚJ0, p. 5). 
A Cartilha 4 (MIRANDA; PRESTA, 2009, p. 19) apresenta um quadro diagnóstico sobre o estágio em que se encontram as crianças e depois recomenda:

A ideia é que esta tabela, além de possibilitar a você acompanhar a evolução da hipótese de escrita do seu aluno, ajude-o a compor agrupamentos e a propor socializações produtivas entre as crianças. Por exemplo, você pode colocar juntas duas crianças como hipótese pré-silábica, uma que ainda não controla a quantidade de letras ao escrever com outra que já tenha esse controle, uma que ainda não usa a variedade de letras como critério para escrever com outra que já usa esse critério ${ }^{18}$.

Há pouca menção a outros aspectos relevantes que devem acompanhar um programa de alfabetização. Apenas um Manual fala a respeito de caligrafia, conforme já citado anteriormente, ao dizer que a caligrafia pode ser ensinada, eventualmente. Outro fala a respeito de ditado, recomendando o uso de ditado acompanhado com a elaboração de regras pelos próprios alunos.

Em sua grande maioria, os Manuais se resumem a (1) apresentar ideias gerais sobre alfabetização ou estágios de alfabetização e (2) explicar como o livro deve ser usado. Ou seja, não há uma orientação específica sobre como ensinar ao aluno a decifrar o código alfabético.

\section{Os métodos de alfabetização}

Tratamos de analisar as cartilhas para depreender alguma proposta metodológica para o ensino da leitura.

Duas das 19 cartilhas possuem um método mais definido, embora não explícito. Uma delas adota algo parecido com o método global, ou seja, o aluno aprende palavras e as usa como referência para aprender outras palavras. Trata-se do método global por analogia. A outra adota o método silábico: o aluno é levado a ler e escrever palavras a partir da análise e síntese de sílabas (juntar e separa sílabas para formar palavras). Nas demais 17 cartilhas não foi possivel identificar nenhum método - seja ele analítico, sintético, global, eclético ou de qualquer natureza.

0 termo "método" de alfabetização aparece raras vezes no Manual do Professor, e, quase sempre, é usado para descaracterizar sua importância. Não há discussão sobre métodos, no máximo, referências ao texto já citado de Madga Soares que minimiza a questão dos métodos e diz que existem vários métodos para os vários aspectos do processo de alfabetização e letramento. Na prática, a maioria das cartilhas esposa os mesmos princípios - o aluno deve descobrir o princípio alfabético fazendo hipóteses

18 A citação lembra o texto evangélico: “Pode um cego guiar um outro cego?” (Lc 6,39-42) 
sobre o valor fonético das letras. Isso ocorrerá, ou não, dependendo do esforço individual do aluno ou daquilo que o professor efetivamente fizer na sala de aula - independentemente da cartilha ou das orientações constantes do Manual do Professor.

\section{A proposta de alfabetização das cartilhas na prática}

0 propósito dos autores das cartilhas é ajudar o professor a alfabetizar os alunos. Resta, portanto, entender como funciona a proposta das cartilhas. Ilustramos com dois exemplos de cartilhas, A e B, que são representativas do conjunto. Concentramos a análise apenas nas atividades pertinentes aos aspectos centrais da alfabetização. Apresentamos, na primeira coluna, as atividades propostas e, na segunda coluna, antecipamos algumas das dificuldades que o aluno poderá enfrentar diante dessa proposta.

\section{Cartilha A: o método da quase silabação}

Escolhemos a cartilha A por ser ela a mais estruturada e a que mais se aproxima de uma cartilha convencional. Na cartilha $A$, há um texto inicial. A lição analisada enfatiza a letra B. Nas lições anteriores foram apresentadas todas as letras e 0 aluno aprendeu a identificar as vogais, consoantes e sons nasais. E aprendeu a emendar

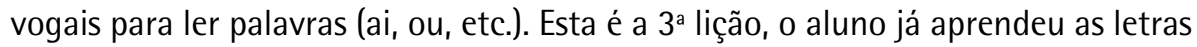
$\mathrm{P}$ e L usando uma estrutura idêntica à apresentada abaixo. Essa estrutura, com esse mesmo tipo e quantidade de atividades, é usado nas demais lições: 


\begin{tabular}{|c|c|}
\hline 0 que a atividade pede & Desafios para o aluno \\
\hline $\begin{array}{l}\text { Escrever o número de letras e sílabas da pala- } \\
\text { vra "bala" }\end{array}$ & - \\
\hline Completar palavras com Bo, Ba, BuEx:___ tão & \\
\hline $\begin{array}{l}\text { Bala, Bola, Bula.O aluno deve perceber:a- qual } \\
\text { letra mudoub- que a mudança de letras muda } \\
\text { a palavra }{ }^{19}\end{array}$ & \\
\hline $\begin{array}{l}\text { Formar palavras a partir de silabas conheci- } \\
\text { das (pa, ba, la) }\end{array}$ & - \\
\hline $\begin{array}{l}\text { Ler o nome dos animais e separar em aquáti- } \\
\text { cos e terrestres }\end{array}$ & $\begin{array}{l}\text { - o aluno deve ser capaz de ler (silabando), pois } \\
\text { todas as palavras são formadas por silabas co- } \\
\text { nhecidas.- ele pode ter dificuldade para saber o } \\
\text { que são animais aquáticos e terrestres (caso típi- } \\
\text { co de confundir leitura com compreensão) }\end{array}$ \\
\hline $\begin{array}{l}\text { Adivinha: o professor lê uma adivinha, o alu- } \\
\text { no deve } \\
\text { a - responder (oralmente) } \\
\text { b - desenhar o objeto (botão) }\end{array}$ & - \\
\hline $\begin{array}{l}\text { Leitura de texto com palavras que contêm sí- } \\
\text { labas desconhecidas }\end{array}$ & - o aluno não sabe ler, a tarefa é impossivel \\
\hline $\begin{array}{l}\text { Completar frases com o nome de figuras(as } \\
\text { palavras são formadas por sílabas canônicas) }\end{array}$ & $\begin{array}{l}\text { - Basta olhar a figura para escrever a palavra. } \\
0 \text { aluno não saberá ler a frase (pois ela con- } \\
\text { tém grafemas não estudados). }\end{array}$ \\
\hline $\begin{array}{l}\text { Completar frases escrevendo o nome próprio e } \\
\text { o de colegas }\end{array}$ & $\begin{array}{l}\text { - Escrever o nome próprio não revela domínio } \\
\text { do código alfabético, pois normalmente é } \\
\text { aprendido como um desenho. Essa aprendiza- } \\
\text { gem afeta o lado direito do cérebro. - Escrever } \\
\text { o nome de colegas só teria função didática se } \\
\text { isso levasse à aprendizagem das correspon- } \\
\text { dências grafema-fonema. Sem isso, o aluno } \\
\text { tem que adivinhar (ou fazer hipóteses) sobre } \\
\text { quais letras usar. }\end{array}$ \\
\hline Copiar palavras dentro de quadradinhos & - Nenhuma \\
\hline
\end{tabular}

Quadro 5 - Estratégia pedagógica da cartilha A. Fonte: 0 autor (2010).

Esse tipo de abordagem guarda algumas semelhanças com o método silábico - o antigo ba-be-bi-bo-bu: por meio da manipulação de sílabas o aluno seria levado a inferir o princípio alfabético ou seja, descobrir que quando se muda uma letra muda-se o som e o sentido da palavra. 0 aluno

19 Numa proposta didática adequada, esse tipo de exercício seria feito oralmente, para ajudar o aluno a identificar a permanência do fonema inicial /b/. Ou seja, a ênfase deveria ser no fonema (relativo à letra que não mudou). 
também teria que descobrir, por esforço próprio, a valência ou valor dos fonemas em diferentes posições da palavra (por exemplo, ele teria que inferir, por esforço próprio que na palavra "bobo" o primeiro "o" se pronuncia "ô" e o segundo se pronuncia "u" átono. Ou seja, trata-se de um esforço menos árduo do que o proposto por Frank Smith (1971), mas mesmo assim, trata-se de um esforço não trivial.

Esta abordagem - também presente nas demais cartilhas analisadas - ignora 0 princípio básico da sobrecarga cognitiva: ao mesmo tempo em que realiza essas descobertas, o aluno ainda tem que compreender, por exemplo, quais são os animais terrestres e aquáticos. Não se trata de um esforço sobre-humano, mas, sem dúvida, trata-se de um esforço que gera sobrecarga cognitiva e impede qualquer tipo de aprendizagem significativa.

\section{Estratégia pedagógica da cartilha $B$}

A cartilha B (Quadro 6) pode ser vista como prototípica do grupo, pois a maioria das cartilhas da amostra se aproxima de sua estrutura. Ela possui unidades - organizadas por temas. Dentro de cada unidade há uma série de lições com leituras ilustrando o tema com o uso de gêneros e tipos de texto variados. Cada lição possui blocos definidos de atividade, relativos ao entendimento do gênero, à compreensão do texto, à produção de texto, ao trabalho com letras e com palavras. Concentramos nas atividades que apresentam alguma pertinência com a alfabetização.

\begin{tabular}{|l|l|}
\hline 0 que a atividade pede & Desafios para o aluno \\
\hline $\begin{array}{l}\text { Ler o nome de brinquedos no texto. Separar as } \\
\text { palavras em silabas e letras }\end{array}$ & $\begin{array}{l}\text { - Ler. O aluno não aprendeu a decodificar as } \\
\text { palavras, portanto, a tarefa é impossivel. - As } \\
\text { atividades de segmentação em silabas e letras } \\
\text { são fáceis, mas não levam, automaticamente, } \\
\text { à identificação do fonema. O aluno terá de } \\
\text { dar esse passo sozinho. }\end{array}$ \\
\hline Copiar as palavras que vogais & - \\
\hline Circular palavras que rimam & $\begin{array}{l}\text { - O aluno, que não aprendeu a ler, precisaria: } \\
(1) \text { identificar uma palavra (2) identificar ou- } \\
\text { tra palavra que rima com ela. - Como o aluno } \\
\text { não sabe ler, ele precisaria ter uma memória } \\
\text { extraordinária para lembrar-se da palavra que } \\
\text { rima. Ou usar algum tipo de pista que lhe per- } \\
\text { mita identificar letras em comum na parte } \\
\text { final da palavra. }\end{array}$ \\
\hline Fazer uma lista de brinquedos & $\begin{array}{l}\text { - Como o aluno não sabe escrever, só lhe } \\
\text { resta copiar algo que a professora escrever } \\
\text { no quadro. }\end{array}$ \\
\hline \hline
\end{tabular}


(continuação)

\begin{tabular}{|l|l|}
\hline $\begin{array}{l}\text { Marque um X em brinquedos de ontem que } \\
\text { ainda existem hoje }\end{array}$ & $\begin{array}{l}-0 \text { aluno precisa saber ler, como não sabe } \\
\text { ler, não tem como fazer a atividade. Obser- } \\
\text { vação: Se o objetivo da atividade for o de } \\
\text { compreensão, seria mais adequado usar fi- } \\
\text { guras, e não palavras. } \\
-\end{array}$ \\
$\begin{array}{l}\text { Ler uma lista de letras e identificar as conso- } \\
\text { antes }\end{array}$ & $\begin{array}{l}\text { - O aluno não sabe ler, não tem como reler sem } \\
\text { ajuda. Ele poderia apenas copiar palavras. }\end{array}$ \\
\hline Reler palavras e circular as consoantes & $\begin{array}{l}\text { - Como o aluno não sabe ler, ele só pode res- } \\
\text { ponder ao acaso. }\end{array}$ \\
\hline $\begin{array}{l}\text { Complete as palavras com consoantes que fal- } \\
\text { tam (palavras com letras m,s, d, b r } n \text { q d }\end{array}$ & $\begin{array}{l}\text { Procure em jornais e revistas uma palavra que } \\
\text { inicie com cada consoante }\end{array}$ \\
\hline $\begin{array}{l}\text { Escreva palavras que você já sabe escrever so- } \\
\text { zinho }\end{array}$ & $\begin{array}{l}\text { - O exercício não apresenta dificuldade. O alu- } \\
\text { no pode ter memorizado a forma visual das } \\
\text { palavras. Mas isso não demonstra domínio do } \\
\text { funcionamento do código alfabético. }\end{array}$ \\
\hline
\end{tabular}

Quadro 6 - Estratégia pedagógica da cartilha B.

Fonte: 0 autor (2010).

A alfabetização, como proposto por Kenneth Goodman (1967), é entendida como um jogo psicolinguístico de adivinhação. A criança é exposta a textos e palavras e, por analogias, metáforas ou pura adivinhação, com ou sem a ajuda do professor é levada a descobrir o funcionamento do código alfabético e, assim, a "ler" e a "escrever" palavras, ao mesmo tempo em que torna letrada.

Essa proposta - típica das cartilhas analisadas - reflete, de maneira consistente, as orientações pedagógicas dos PCNs e os conceitos que são transmitidos em cursos como os do Proletramento. $E$, em consequência, na medida em que são efetivamente usadas, ela é típica do que ocorre efetivamente nas salas de aula. Embora não tenham sido objeto de análise como a aqui realizada, cartilhas elaboradas nos últimos três anos pelas Secretarias de Educação dos Estados do Ceará, São Paulo, Minas Gerais e município do Rio de Janeiro apresentam essas mesmas caracteristicas.

\section{Discussão}

0 objetivo do presente trabalho foi o de detectar como as cartilhas aprovadas pelo FNDE/PNLD, elaboradas com base no paradigma de alfabetização predominante no Brasil, iriam abordar duas exigências do Edital do referido programa, referentes ao tratamento de duas questões centrais no processo de alfabetização: o ensino da decodificação, ou seja, das relações fonema/grafema e o desenvolvimento da fluência. 
Conforme documentado a partir da análise das atividades propostas na cartilha, as aquelas voltadas para esses aspectos centrais da alfabetização ocupam menos de 1\% do total das atividades das cartilhas. Mesmo se incluissemos aquelas voltadas para o ensino da ortografia, esse total não chegaria a $10 \%$ das atividades. Por outro lado, outras voltadas para a compreensão e produção de textos ocupam mais de 70\% das cartilhas. E não há nenhuma menção, nas cartilhas ou nos Manuais do Professor, às atividades voltadas para o desenvolvimento da fluência de leitura. Resta compreender (a) por que os autores da cartilha não valorizam as atividades de decodificação e fluência de leituras e (b) por que nem eles nem as autoridades do MEC se preocupam em atender a esses requisitos do Edital.

0 papel secundário atribuído pelos autores das cartilhas aos aspectos da decodificação decorre de sua orientação teórica, a qual se tornou uma unanimidade nas orientações oficiais e no ensino ministrado nas Universidades. De acordo com os princípios apresentados nos PCNs e no próprio corpo do Edital, a ênfase se dá à compreensão e produção de textos. Em nenhum dos documentos e referências em que se baseiam os autores há uma definição clara de alfabetização e, muito menos, orientações no sentido de que a decodificação deva constituir o cerne de uma proposta de alfabetização. Portanto, trata-se de uma coerência e de uma consistência - ainda que isso implique ignorar os avanços científicos e os termos do Edital. Não são raros os casos, nem na História, nem na História da Ciência, em que a ideologia prejudica uma análise mais objetiva da realidade.

0 fato de as crianças não se alfabetizarem também não coloca em questão a ineficácia desse tipo de proposta. Há uma argumentação, também hegemônica, de que as novas ideias disseminadas pelos PNCs ainda não tiveram tempo de ser implementadas, e, portanto, os resultados não surgiram por conta de uma implementação ainda incipiente.

Os mesmos argumentos anteriores podem explicar o descumprimento dos requisitos do Edital referentes às questões da decodificação e da fluência. 0 Edital de 2008 2010 (BRASIL, 2006) inclusive era bastante mais explícito do que o Edital de 2010 (BRASIL, 2008), no sentido de insistir em que a maior ênfase das cartilhas deveria ser nos aspectos da decodificação. No Edital de 2010 essa insistência foi atenuada, mas permaneceram de forma explicita as exigências para que as cartilhas lidassem com 0 ensino das relações fonema/grafema. Poderia haver duas explicações para a ausência desses requisitos. A primeira delas, de natureza teórica, é que o ensino das relações grafema-fonema, na perspectiva teórica ou entendimento dos autores das cartilhas, é algo que se faz de maneira automática, trata-se de uma descoberta que as crianças farão naturalmente ao longo do processo de alfabetização. Portanto, dessa perspectiva, tratar-se-ia de uma exigência absurda do PNLD que não pode ser cobrada explicitamente - caberá ao professor, ou melhor, ao aluno, fazer essas descobertas. A segunda, decorrente do enfoque teórico, é que não é necessário ensinar explicitamente a relação fonema-grafema, basta expor o aluno a situações em que ele levantará 
hipóteses sobre essas relações e, com a ajuda do professor e dos colegas, irá terminar por descobri-las. Portanto, dentro dessa concepção, as exigências do Edital referentes ao ensino da decodificação estariam cumpridas. Quanto à omissão dos aspectos referentes à fluência, este item não consta das preocupações dos formuladores das teorias de alfabetização predominantes do Brasil. Portanto, trata-se simplesmente do descumprimento de uma cláusula contratual. 0 mesmo raciocínio se aplica à Comissão de Avaliação das Cartilhas, que não só partilha, mas promove ativamente essas mesmas concepções através das publicações do Proletramento e do CEALE/UFMG.

No caso das editoras e dos autores, essa postura pode-se explicar pelo temor de ver as cartilhas reprovadas pelo Comitê de Avaliação, cujas orientações e publicações são bem conhecidas. Trata-se, portanto, de um cálculo racional: ainda que eles conheçam ou mesmo reconheçam o status científico das pesquisas sobre alfabetização, eles agem racionalmente ao utilizar os conceitos, referências e abordagens que maximizam a aprovação pelo Comitê de Avaliação.

Da mesma forma, poder-se-ia arguir por que o MEC que explicitou os critérios de inclusão desses dois elementos no Edital não insiste em que eles sejam cumpridos. As explicações também podem surgir tanto de reflexões teóricas quanto de natureza organizacional. Pode-se argumentar que esses itens foram inseridos nos Editais, especialmente no Edital de 2010 (BRASIL, 2008), por insistência explícita do Ministro da Educação. 0 Ministro Fernando Haddad (PARA..., 2006), de modo especial, tentou, sem sucesso, suscitar o debate sobre métodos de alfabetização tanto no âmbito interno do Ministério quanto na mídia. E, explicitamente, vem abrindo espaço, dentro de vários programas do MEC, para concepções de alfabetização que não sejam estritamente vinculadas ao paradigma construtivista ${ }^{20}$.

0 que se vê, portanto, pode ser uma estratégia institucional de desimplementação. Os itens centrais da solicitação do ministro - ênfase na decodificação e na fluência - foram inseridos numa proposta que, em sua formulação, desconstrói a importância desses itens, tornando-os, talvez, meros registros formais. A isso se acoplaria a ideia de que as decisões do Comitê de Avaliação são irrecorriveis, isentando, portanto, a máquina burocrática de qualquer responsabilidade. Resta ver se um órgão como o Tribunal de Contas da União teria esse mesmo entendimento, por se tratar de um descumprimento explícito dos requisitos do Edital já citado, no qual se lê que a 'não observância de qualquer um dos critérios apontados resulta em exclusão'.

Os problemas, portanto, remetem ao princípio, à própria definição de alfabetização. Dele decorrem todos os demais. A definição de alfabetização adotada nos

20 Há programas de alfabetização aprovados no Guia de Tecnologias Educacionais do MEC que adotam metodologias não construtivistas, inclusive metodologias que explicitamente adotam os métodos fônicos preconizados pela Ciência Cognitiva da Leitura. Também, por meio de outras instâncias, o MEC tem apoiado iniciativas de estados e municípios que adotam essas metodologias que fogem ao paradigma dominante. 
PCNs, no Proletramento (BATISTA, 2006) e no Edital do PNLD (BRASIL, 2008) é, na melhor das hipóteses, ambígua. Ela sempre vem associada ao conceito de letramento e, em nenhum momento, apresenta qualquer formulação concreta. A definição de letramento, por sua vez, é incompreensivel: como seria possivel saber se alguém está letrado? Isso é algo que se aprende ao longo de um ano letivo? Dois?

Daí para frente os conceitos se tornam mais confusos. Por exemplo, a ideia central é que alfabetização e letramento são indissociáveis. Essa ideia se afigura como lógica e psicologicamente equivocada. Para ser logicamente correta, seria necessário provar que uma pessoa não pode alfabetizar-se sem se letrar. E que, depois de se alfabetizar, não pode mais se letrar, pois os termos são indissociáveis. Logicamente essa indissociabilidade não se sustenta.

Mas, é do ponto de vista psicológico que o conceito da suposta indissociabilidade entre alfabetização e letramento é mais vulnerável, sobretudo dadas suas implicações e a violação de princípios básicos da psicologia da aprendizagem e da didática. A primeira violação é que só se pode alfabetizar a partir de textos "autênticos". Com isso, o critério para escolha da ordem dos fonemas fica subordinado a um critério textual ou semântico, e não a um critério próprio do código alfabético - como, por exemplo, a facilidade maior ou menor para identificar determinados fonemas ou grafemas. Segundo, essa abordagem reforça o uso incidental de palavras - contrapondo-se à evidência científica a respeito da importância da apresentação sistemática e explícita dos fonemas. Terceiro, essa abordagem ignora o princípio básico de partir do simples para o complexo - como vimos em vários exemplos, antes de saber ler, o aluno é levado a procurar palavras que não sabe ler no meio de um texto ou de um exercício de palavras cruzadas. Quarto, ela ignora o princípio da consistência - o aluno é levado a descobrir a palavra usando diferentes estratégias: o título do texto, as ilustrações, a forma da letra, a posição da palavra ou mesmo pistas fonológicas: a evidência empírica mostra que essa estratégia é danosa à aprendizagem e caracteriza os maus, e não os bons leitores (Perfetti, 1985). Finalmente ela ignora o princípio básico da sobrecarga cognitiva: se o aprendiz é induzido a pensar ao mesmo tempo no sentido do texto, em descobrir a palavra, o seu sentido, a sua grafia e tantas outras exigências, a memória de curto prazo entra em curto-circuito e inibe processos efetivos de aprendizagem.

\section{A sociologia política da alfabetização: desafios para mudança de paradigma}

A análise apresentada no presente estudo deixa claro que as cartilhas brasileiras se baseiam no paradigma comumente associado ao termo "construtivismo" e cujas concepções são difundidas em documentos oficiais como os PCNs, os textos do curso Proletramento e pelos autores mais citados por essas fontes e pelos autores das cartilhas. 
A análise também deixa claro que há um fosso entre as concepções e práticas adotadas no Brasil e as conclusões e recomendações da Ciência Cognitiva da Leitura. 0 fato de que nenhum autor ou obra relevante desse paradigma seja citado sugere a existência de um bloqueio de natureza ideológica, pois não é razoável admitir que as autoridades do MEC, a comunidade acadêmica e os autores das cartilhas ignorem a existência dessa literatura. 0 não reconhecimento e a omissão dessa literatura, portanto, só podem ocorrer de maneira intencional e propositada. Trata-se de uma convicção segmentada em documentos oficiais e imune, portanto, a questionamentos, inclusive argumentos baseados em evidências científicas.

Nos últimos 20 anos, vem surgindo na educação um movimento denominado "educação baseada em evidências". Esse movimento, inspirado no avanço das práticas de atendimento médico, vem evoluindo lentamente, inclusive nos paises desenvolvidos. Em grande parte isso se deve à falta de evidências sólidas a respeito de intervenções eficazes em educação (GORARD; COOK, 2007). E, em maior parte, isso se deve à falta de condições para alterar os paradigmas vigentes. Clermont Gauthier (2010) e Walsh, Glaser, e Wilcox (2006) analisaram como, no Canadá e nos Estados Unidos, respectivamente, as revistas profissionais de educação e as faculdades de educação andam na direção contrária à evidência científica. No caso do Canadá, o artigo de Gauthier (2010) mostra que quanto mais forte se tornava a evidência a respeito da pedagogia centrada no ensino, mais aumentavam os artigos sobre ensino centrado no aluno. No caso dos Estados Unidos, o artigo de e Walsh, Glaser, e Wilcox (2006) mostra que nenhuma faculdade de educação chegou a implementar as cinco recomendações do NRPR nos cursos de formação de professores alfabetizadores. 0 panorama é ligeiramente diferente nos Ministérios de Educação. Em paises como Estados Unidos, Austrália, França e Inglaterra, de modo geral, as orientações curriculares têm convergido no sentido de estabelecer recomendações cada vez mais específicas e cada vez mais sedimentadas em evidências científicas robustas. Em paises com tradição mais descentralizada, como a Finlândia e os paises germânicos, essas orientações passam mais pelos sistemas de formação de professores.

As evidências a respeito de métodos de alfabetização estão muito bem estabelecidas. Estudos recentes da neurociência vêm confirmando o resultado dos estudos de laboratório realizados na década de 90 e os estudos empíricos realizados nas duas últimas décadas. Com base na revisão desses estudos, e de suas próprias e importantes contribuições, Dehane (2007, p. 291) desvendou os "neurônios da leitura" e afirma que "a conversão grafema-fonema é uma invenção única na história da escrita, que transforma radicalmente o cérebro da criança e sua maneira de ouvir os sons da língua. Ela não se manifesta espontaneamente, portanto, é preciso ensinar."

A ciência é um ato de fé. Pesquisadores acreditam nos resultados da evidência científica, embora os reconheçam como sempre provisórios e sujeitos a serem refutados. A educação baseada em evidências e a Ciência Cognitiva da Leitura não é um 
conjunto de dogmas: ela representa o estado atual de conhecimentos sobre esse campo. Negar essas evidências significa negar a validade da ciência. É nesse campo, contrário à ciência, que se encontram os que ainda defendem os atuais métodos de alfabetização adotados no Brasil. Tal atitude tem, como resultado, a desvalorização da evidência científica e da razão como instrumento capaz de iluminar as práticas pedagógicas. Uma pedagogia que não se curva às evidências da ciência se torna ideológica. Ideologias levam ao fanatismo. Recusar a evidência científica leva ao subjetivismo e ao retorno à alquimia, e, consequentemente, o magistério deixa de ser uma profissão para se converter em magia.

\section{Referências}

ACADEMIA BRASILEIRA DE CIÊNCIAS. A importância da educação infantil: relatório. Rio de Janeiro: $A B C, 2009$.

ADAMS, M. J. Beginning to read: thinking and learning about print. Cambridge, MA: MIT Press, 1990.

ALMEIDA, P. N. Leitura, expressão, participação. São Paulo: Saraiva, 2009. Cartilha 18.

ARÊDES, A.; ALEXANDREF, A.; GRILO, M. Infância feliz. São Paulo: Escala Educacional, 2009. Cartilha 9.

AROEIRA, M. L. C.; COSA, S.; ALMEIDA, Z. Aventura da linguagem. Belo Horizonte: Dimensão, 2009. Cartilha 7.

BATISTA, A. A. Pró-Letramento: programa de formação continuada de professores dos anos/séries iniciais do Ensino Fundamental. Brasilia, DF: MEC; Belo Horizonte: UFMG, CEALE, 2006. Fascículo do tutor, p. 13.

BRASIL. Câmara dos Deputados. Alfabetização infantil: novos caminhos: relatório apresentado à Comissão de Educação e Cultura... Brasília, DF, 2003.

BRASIL. Ministério da Educação. Fundo Nacional de Desenvolvimento da Educação. Secretaria de Educação Básica. Programa Nacional do Livro Didático: PNLD 2008: edital de convocação... Brasilia, DF, 2006.

BRASIL. Ministério da Educação. Fundo Nacional de Desenvolvimento da Educação. Secretaria de Educação Básica. Programa Nacional do Livro Didático: PNLD 2010: edital de convocação... Brasilia, DF, 2008. Disponivel em: <ftp:// ftp.fnde.gov.br/web/livro_didatico/edital_pnld_2010_consolidado.pdf>. Acesso em: jun. 2010. 
BRASIL. Ministério da Educação. Secretaria de Educação Fundamental. Parâmetros curriculares nacionais: introdução aos parâmetros curriculares nacionais. Brasilia, DF, 1997.

BURANELLO, C. Conhecer e crescer. São Paulo: Escala educacional, 2009. Cartilha 8.

CAMPEDELLI, S. Hoje é dia de português. São Paulo: Positivo, 2009. Cartilha 14.

CARDOSO MARTINS, C.; SILVA, J. Cognitive and language correlates of hyperlexia: evidence from children with autism spectrum disorders. Reading $\&$ Writing, n. 23, p. 129-145, 2010.

CARPANEDA, I. ; BRAgAnÇA, A. Porta aberta. São Paulo : FTD, 2009. Cartilha 13. CARVAlHO, C. S. et al. Construindo a escrita. São Paulo: Ática, 2009. Cartilha 2. CARVALHO, R. ; ANSON, V. R. A grande aventura. São Paulo: FTD, 2009. Cartilha 10. CAVÉOUIA, M. P. A escola é nossa. São Paulo: SCIPIONE, 2009. Cartilha 19. CEREJA, W. R.; MAGALHÃES, T. C. Português: linguagens. São Paulo : Atual, 2009. Cartilha 5. CIPRIANO, L. H. R. ; WANDRESEN, M. O. L. Linhas e entrelinhas. São Paulo: Positivo, 2009. Cartilha 15.

DEHAENE, S. Les neurones de la lecture. Paris: Odile Jacob, 2007.

EHRI, L. C. et al. Systematic phonics instruction helps students learn to read: evidence from the National Reading Panel's Meta-Analysis. Review of Educational Research, Washington, DC, v. 71, n. 3, p. 393-447, 2001.

ESPI, P.; ARAÚJO, J. G. Alfaletra. São Paulo: Ática, 2009. Cartilha 3.

FERREIRO, E. Reflexões sobre a alfabetização. São Paulo: Cortez, 1989.

FERREIRO, E.; TEBEROSKY, A. A psicogênese da escrita. Porto Alegre, RS: Artes Médicas, 1986.

FRITH, U. Beneath the surface of developmental dyslexia. In: PATTERSON, K. E.; MARSHAL, J. C.; COLTHEART, M. (Ed.). Surface dislyexia: cognitive and Neuropsychological Studies of Phonological Reading. Hilsdale, NJ: Lawrence Earlbaum, 1985. 
GARCIA, E. Língua e linguagem. São Paulo: Saraiva, 2009. Cartilha 17.

GAUTHIER, C. Sucesso acadêmico e reformas educativas. In: OLIVEIRA, J. B. A. (Org.). Pedagogias eficazes: o que funciona na sala de aula. Brasilia, DF: Instituto Alfa e Beto, 2010.

GIESEN, M. R.; GARCIA, V. A. Descobrindo a vida: alfabetização. São Paulo: Ed. do Brasil, 2009. Cartilha 11.

GOODMAN, K. S. A linguistic study of cues and miscues in reading. Elementary English, n. 42, p. 639-643, 1965.

Reading: a psycholinguistic guessing game. Journal of the Reading Specialist, v. 4, n. I, p. 11-30, 1967.

GORARD, S.; COOK, T. Where does good evidence come from?. International Journal of Research \& Method in Education. v. 30, n. 3, p. 307-323, Nov. 2007.

HIRSCHMAN, E. D. Reading comprehension requires knowledge of words and the world. American Educator, Washington DC, n. 10, p. 10-44, Spring 2003.

JOHNSTON, R.; WATSON, J. A seven year study of the effects of synthetic phonics teaching on reading and spelling attainment: scottish executive. Insight 17, Scotland, UK, 2005.

KEENAN, J. M.; BETJEMANN, R.S. Comprehending the Gray Oral Reading Test without reading it: why comprehension tests should not include passageindependent items. Scientific Studies of Reading, Cameron, M0, v. 10, p. 363380, 2007.

KEENAN, J.; BETJEMANN, R. S.; OLSON. R. K. Reading compreension tests vary in the skills they assess: Differential dependence on decoding and oral comprehension. Scientific Studies of Reading, Cameron, M0, v. 12, n. 3, p. 281300, 2008.

LABERGE, D.; SAMUELS, S. J. Toward a theory of automatic information processing in reading. Cognitive Psychology, Nashville, TN, n. 6, p. 293-323, 1974.

LEITE, M.; MORELLI, B.; GUIMARÃES, L. Leitura, escrita e reflexão. São Paulo: FTD, 2009. Cartilha 12. 
MCGUINNESS, D. Early Reading Instruction. Cambridge, MA: MIT Press, 2004. Language development and learning to read. Cambridge, MA: MIT Press, 2005.

MIRANDA, C.; PRESTA, E. Pensar e viver. São Paulo: Ática, 2009. Cartilha 4.

MIRANDA, C.; RODRIGUES, V. L. Aprendendo sempre. São Paulo: Ática, 2009. Cartilha 1.

NATION, K.; SNOWLING, M. Assessing reading difficulties: the validity and utility of current measures of reading skill. British Journal of Educational Psychology, v. 67, p. 359-370, 1997.

NATIONAL EARLY LITERACY PANEL. Developing Early Literacy: report of the National Early Literacy Panel. Washington, DC: National Institute for Literacy, 2008.

NATIONAL READING PANEL REPORT. Teaching children to read: An evidencebased assessment of the scientific literature on reading and its implications for reading instruction. Bethesda, MD: National Institute of Child Health and Human Development, 2000.

OBSERVATOIRE NACIONAL DE LA LECTURE. Apprendre à lire. Paris: Éditions Odile Jacob: CNDP, 1998.

OLIVEIRA, L. O. Vivenciando a linguagem. São Paulo: Atual, 2009. Cartilha 6.

PARA ministro, método de ensino deve ser revisado [entrevista com o Ministro Fernando Haddad]. Folha de S. Paulo, São Paulo, 7 fev. 2006. Cotidiano, não paginado. Disponivel em: <http://www1.folha.uol.com.br/fsp/cotidian/ ff0702200612.htm>. Acesso em: 14 dez. 2010.

PERFETII, C. Reading ability. New York. Oxford University Press, 1985.

PERFETTI, C. The universal grammar of reading. Scientific Studies of Reading, Cameron, MO, v. 7, n. 1, p. 3-24, 2003.

PRADO, A.; H6LE, C. Projeto prosa. São Paulo: Saraiva, 2009. Cartilha 16.

RIO DE JANEIRO. Secretaria Municipal de Educação. Orientações curriculares: áreas 
específicas. Rio de Janeiro, 2010. Disponível em: <http://200.141.78.79/dlstatic/ 10112/825382/DLFE-197212.pdf/oclprevfinal19anos.pdf>. Acesso em: 17 jun. 2010.

SEYMOUR, P. H. K.; EVANS, H. M. Beginning reading without semantics: a cognitive study of hyperlexia. Cognitive Neuropsychology, London, n. 9, p. 89122, 1992.

SMITH, F. Decoding: the great fallacy. In: SMITH, F. ( Ed.). Psycholinguistics and Reading. New York, NY: Holt, Rinehart \& Winston, 1973.

SMITH, F. Understanding reading. New York, NY: Holt, Rinehart \& Winston, 1971.

SNOW, C. E.; BURNS, M. S.; GRIFFIN, P. (Ed). Preventing reading difficulties in young children. Washington, DC: National Academy Press, 1998.

SOARES, M. Letramento e alfabetização: as múltiplas facetas. Revista Brasileira de Educação, Rio de Janeiro, n. 25, p. 5-17, jan./abr. 2004.

SPRENGLER-CHAROLLES, L.; SIEGEL, L. A longitudinal study of the effects of syllabic structure on the development of reading and spelling skills in French. Applied Psycholinguistics, Cambridge, UK, n. 18, p. 485-505, 1997.

SPRENGLER-CHAROLLES, L.; SIEGEL, L.; BONNET, P. Reading and spelling acquisition in French: the role of phonological mediation and orthographic factors. J. Exp. Child Psychology, v. 68, n. 2, p. 134-165, 1998.

WALSH, K.; GLASER, D.; WILCOX, D. D. What education schools aren't teaching about reading and what elementary teachers aren't learning?. Washington, DC: NCTQ, 2006.

Recebido em: 20/07/2010

Aceito para publicação em 21/09/2010 


\section{Anexo A - Relação das cartilhas analisadas por ordem de editores.}

\begin{tabular}{|c|c|c|}
\hline Título & Autor & Editora \\
\hline Aprendendo sempre & $\begin{array}{l}\text { Cláudia Miranda } \\
\text { Vera Lúcia Rodrigues }\end{array}$ & Ática \\
\hline Construindo a escrita & $\begin{array}{l}\text { Carmem Silvia Carvalho } \\
\text { Cristina Nogueira } \\
\text { Déborah Panachão } \\
\text { Silvia Salmaso }\end{array}$ & Ática \\
\hline Alfaletra & $\begin{array}{l}\text { Pilar Espi } \\
\text { Jaqueline de Grammont Araújo }\end{array}$ & Ática \\
\hline Pensar e Viver & $\begin{array}{l}\text { Cláudia Miranda } \\
\text { Eliete Presta }\end{array}$ & Ática \\
\hline Português Linguagens & $\begin{array}{l}\text { William Roberto Cereja } \\
\text { Thereza Cochar Magalhães }\end{array}$ & Atual Editora \\
\hline Vivenciando a Linguagem & Lourdes Sirtoli de Oliveira & Base \\
\hline Aventura da Linguagem & $\begin{array}{l}\text { Maria Luisa Campos Aroeira } \\
\text { Silvana Cosa } \\
\text { Zélia Almeida }\end{array}$ & Dimensão \\
\hline Conhecer e Crescer & Cristiane Buranello & Escala Educacional \\
\hline Infância Feliz & $\begin{array}{l}\text { Albanize Arêdes } \\
\text { Ângelo Alexandref } \\
\text { Miriam Grilo }\end{array}$ & Escala Educacional \\
\hline A grande aventura & $\begin{array}{l}\text { Regina Carvalho } \\
\text { Vera Regina Anson }\end{array}$ & FTD \\
\hline Coleção Novo Bem me Quer & $\begin{array}{l}\text { Maria Regina } \\
\text { Giesen Vanda A. Garcia }\end{array}$ & Editora do Brasil \\
\hline Leitura, escrita e reflexão & $\begin{array}{l}\text { Márcia Leite } \\
\text { Beatriz Morelli } \\
\text { Luciana Guimarães }\end{array}$ & FTD \\
\hline Porta Aberta & $\begin{array}{l}\text { Isabella Carpaneda } \\
\text { Angiolina Brangança }\end{array}$ & FTD \\
\hline Hoje é dia de Português & Samira Campedelli & Positivo \\
\hline Linhas e Entrelinhas & $\begin{array}{l}\text { Lucia Helena Ribeiro Cipriano } \\
\text { Maria Otilia Leite Wandresen }\end{array}$ & Positivo \\
\hline Projeto Prosa & $\begin{array}{l}\text { Angélica Prado } \\
\text { Chistina H6lle }\end{array}$ & Saraiva \\
\hline Lingua e Linguagem & Eliana Garcia & Saraiva \\
\hline Leitura, Expressão, Participação & Paulo Nunes de Almeida & Saraiva \\
\hline A escola é nossa & Marcia Paganini Cavéquia & Scipione \\
\hline
\end{tabular}

